\title{
A new type strain of Pseudomonas putida NM-CH-I15-I isolated from a nickel-contaminated soil in southwest Slovakia harbouring the $c z c \mathrm{~A}-\mathrm{NM} 15 \mathrm{I}$ resistance determinant
}

\author{
Nikola Mihalíková ${ }^{1}$, Janka Harichová ${ }^{1}$, Marcel Zámocký ${ }^{1,2}$, Anna Kamlárová ${ }^{3}$ and Peter Ferianc ${ }^{1}$ \\ ${ }^{1}$ Laboratory of Phylogenomic Ecology, Institute of Molecular Biology, Slovak Academy of Sciences, Bratislava, Slovakia \\ ${ }^{2}$ Department of Chemistry, Institute of Biochemistry, BOKU, University of Natural Resources and Life Sciences, Muthgasse 18, \\ A-1190 Vienna, Austria \\ ${ }^{3}$ Institute of Experimental Medicine, Faculty of Medicine, Pavol Jozef Šafárik University, Košice, Slovakia
}

\begin{abstract}
A soil bacterium MR-CH-I15-I was on the base of phylogenetic analysis of almost the whole (1,492 bp) $16 \mathrm{~S}$ rRNA sequence and sequences of selected 9 marker genes identified as Pseudomonas putida strain NM-CH-I15-I. The bacterium exhibited typical morphological features and biochemical properties for this species, the highest resistance to nickel and copper and multidrug resistance to different antibiotic groups. In addition, the whole $c z c \mathrm{~A}-\mathrm{NM} 15 \mathrm{I}$ heavy-metal resistance gene sequence $(3,126 \mathrm{bp}$, 1,042 amino acids, MW 112, 138 Da) was obtained and on the base of phylogenetic analysis was assigned to CzcA protein from Pseudomonas reidholzensis with 93\% similarity. This gene was significantly induced mainly by the addition of zinc, cadmium and cobalt and in a lesser extent of nickel. Furthermore, an increased expression of the CzcA-NM15I protein was confirmed by immunoblot analysis after heterologous expression of the $c z c \mathrm{~A}-\mathrm{NM} 15 \mathrm{I}$ synthetic variant gene in E. coli BL21 (DE3). Finally, the location of amino acids (R83, R673, D402, D408, D619, E415, E568) in the homology model of the CzcA-NM15I protein suggested that these amino acids may play an important role in the transport of cations such as cobalt, zinc or cadmium. This soil bacterium can represent a new type strain of P. putida NM-CH-I15-I.
\end{abstract}

Key words: Pseudomonas putida type strain - Molecular marker genes - czcA resistance determinant - RT-qPCR - Molecular modelling

\begin{abstract}
Abbreviations: ampC, $\beta$-lactamase gene; AP, alkaline phosphatase; atpD, ATP synthase gene (subunit $\beta$ ); carA, carbamoyl-phosphate synthase gene, small chain; $c n r$, heavy-metal-resistance operon (cobalt-nickel resistance); $c z c \mathrm{~A}$, heavy-metal-resistance determinant (cobalt-zinc-cadmium resistance); CzcA, heavy metal efflux pump (cobalt-zinc-cadmium resistance); CzcCBA, metal-dependent efflux driven by the proton motive force (cobalt-zinc-cadmium resistance); D, aspartate; $c z n$, heavymetal-resistance operon (cadmium-zinc-nickel resistance); gdhA, glutamate dehydrogenase gene; gyr B, DNA gyrase gene (subunit $\beta$ ); I, isoleucine; IPTG, isopropyl $\beta$-D-1-tiogalaktopyranosid; $n c c$ A, heavy-metal-resistance determinant (nickel-cobalt-cadmium resistance); NccCBA, heavy metal efflux pump (nickel-cobalt-cadmium resistance); nre, heavy-metal-resistance operon (nickel resistance); py $r \mathrm{H}$, uridylate kinase gene; $\mathrm{R}$, arginine; rDNA, ribosomal DNA; recA, bacterial DNA recombination protein gene; $r p o \mathrm{~A}$, bacterial RNA polymerase gene (subunit $\alpha$ ); $r p o \mathrm{~B}$, bacterial RNA polymerase gene (subunit $\beta$ ); rpoD, bacterial RNA polymerase gene, sigma 70 (sigma D) factor; RND, resistancenodulation-division family transporters; rRNA, ribosomal RNA; RT-qPCR, reverse-transcription quantitative real time PCR; SDS-PAGE, sodium dodecyl sulphate-polyacrylamide gel electrophoresis.
\end{abstract}

Electronic supplementary material. The online version of this article (doi: 10.4149/gpb_2020012) contains supplementary material, which is available to authorized users.

Correspondence to: Peter Ferianc, Institute of Molecular Biology, Slovak Academy of Sciences, Dúbravská cesta 21, 84551 Bratislava, Slovakia E-mail: Peter.Ferianc@savba.sk 


\section{Introduction}

Soil represents very suitable environment for life of diverse groups of microorganisms which have adapted to these conditions and in which they are able to live together with the rest of the units of soil biota in different consortiums (Torsvik and Ovreas 2002). Up to 45 different microbial phyla were identified in different soil microbial assemblages and the most abundant phylum has comprised Proteobacteria ( $\alpha-, \beta-$, $\delta$-, $\gamma$ - and $\left.\varepsilon_{-}\right)$. The second phylum with the most incidences in soil was Firmicutes followed by Actinobacteria and Bacteroidetes (He et al. 2012). In addition to these four phyla, next 5 taxons, Acidobacteria, Verrucomicrobia, Chloroflexi, Planctomycetes, Gemmatimonadetes, comprise an important component of these ecosystems (Greening et al. 2015).

Among Proteobacteria, representatives of the genus Pseudomonas are naturally widespread bacteria in environments and they are known for their ability to colonise soil and degrade a wide range not only of the natural chemical compounds but xenobiotics as well. Pseudomonads dispose with these features due to their great metabolic versatileness (Stanier et al. 1966; Özen and Ussery 2012).

Pseudomonas putida poses one of the main representatives of the genus Pseudomonas. One of the well characterized strains is $P$. putida KT2440 (Nakazawa 2002). The basic feature of this strain is its ability to survive in polluted soils (Nelson et al. 2002). In fact, the species $P$. putida incorporates a lot of strains with broad spectrum of metabolic features and a lot of isolates with unique phenotypes (Wu et al. 2010). However, on account of their adaptability and great metabolic versatileness, representatives of this species are able to colonise not only soils with appropriate conditions for growth but they are able to survive in extreme environmental conditions, such as deserted soils or soils contaminated by different kinds of antibiotics and heavy metals (Ramette and Tiedje 2007).

The soil pollutions by heavy metals present one of very serious problems of $21^{\text {th }}$ century. An increased content of heavy metals in natural environment is caused first of all as an outgrowth of anthropogenic activities and heavy metals reached urban and agricultural soils. Heavy metals in comparison to carbonic substances are not biologically degradable, persisted in soils and they negatively influenced plant growth, microbiological diversity and soil activities and they have strong effects on genetic structures of this biotope as well. Moreover, their contribution in overall contamination of soils in Europe is of about 35\%, what reveals a greater fraction in comparison to mineral oils (Panagos et al. 2013; Sydow et al. 2017). Most known heavy metals are cadmium $(\mathrm{Cd})$, zinc $(\mathrm{Zn})$, copper $(\mathrm{Cu})$, nickel $(\mathrm{Ni})$, lead $(\mathrm{Pb})$, mercury ( $\mathrm{Hg}$ ) and arsenic (As) (Mekki and Sayadi 2017). In general, they are not toxic but when their amount exceeded the acceptable level, they become toxic. For example, $\mathrm{Cd}, \mathrm{Zn}, \mathrm{Cu}$,
$\mathrm{Ni}$ and Co inhibited growth of g-Proteobacteria in heavymetal contaminated soil at concentrations of $500 \mu \mathrm{g} / \mathrm{ml}$ for metal cations (Remenár et al. 2015). On the other hand, some of heavy metals, such as cobalt, copper, iron, manganese, molybdenum, nickel and zinc, are necessary in trace amounts for plant growths (Hussain et al. 2013) and a variety of metabolic processes in the cells (Nies 1999).

In heavy-metal-contaminated soils survived only bacteria which have evolved several mechanisms that are responsible for their resistance against heavy metals. The best-known mechanisms of heavy-metal resistances include permeability barriers, intra- and extra-cellular sequestration, efflux pumps, enzymatic detoxification, and reduction (Nies 1999). The most well characterized operons conveying resistance against heavy metals in Gram-negative bacteria are the $c z c$ (cobalt-zinc-cadmium resistance) and $c n r$ (cobalt-nickel resistance) operons from Cupriavidus metallidurans $\mathrm{CH} 34$ (Mergeay et al. 2003), the ncc (nickel-cobalt-cadmium resistance) and nre (nickel resistance) systems from Achromobacter xylosoxidans 31A (Schmidt and Schlegel 1994) and $c z n$ (cadmium-zinc-nickel resistance) operon from Helicobacter pylori (Salvador et al. 2007). In Gram-positive bacteria, the cad operon from Bacillus and Staphylococcus members has been well studied (Silver and Phung 1996). In both Grampositive and Gram-negative bacteria the ars operons from Escherichia coli (Mobley et al. 1983; Saltikov and Olson 2002) and Staphylococcus strains (Ji and Silver 1992; Rosenstein et al. 1992), and the mer systems from E. coli (Nascimento and Chartone-Souza 2003) and Bacillus populations (Bogdanova et al. 1998) have been characterized. In addition, the cyanobacterial smt locus from Synechococcus PCC 7942 also contains a well-characterized heavy metal resistance system (Erbe et al. 1995).

In our previous work, a few of hardly cultivable and previously uncultured bacterial isolates from toxic-metal contaminated soil were cultivated, partly identified and characterised by using a diffusion chamber approach. One of them, marked as MR-CH-I15-I [KC809952] and tentatively assigned to $\gamma$-Proteobacteria, was found as bacterial isolate that carried $c z c \mathrm{~A}$-like gene encoded protein fragment assigned with $85 \%$ similarity to CzcA protein (Remenár et al. 2015). The $c z c$ determinant encodes resistance against $\mathrm{Cd}^{2+}, \mathrm{Zn}^{2+}$ and $\mathrm{Co}^{2+}$ by metal-dependent efflux driven by the proton motive force (CzcCBA) (Nies 1995). $\mathrm{Ni}^{2+}$ and $\mathrm{Co}^{2+}$ are, in some occasions, exported by the same CBA transporters as $\mathrm{Zn}^{2+}$ and $\mathrm{Cd}^{2+}$ (for example NccCBA from A. xylosoxidans 31A and CzcCBA from C. metallidurans CH34) (Schmidt and Schlegel 1994; Legatzki et al. 2003).

The CzcCBA complex from C. metallidurans $\mathrm{CH} 34$ is the best-characterized CBA transporter (Nies 1995). In detail, CBA transporters are three-component protein complexes that span the whole cell wall of Gram-negative bacteria. The most important component of the transporter is a RND 
protein that is located in the inner membrane. It mediates the active part of the transport process, determines the substrate specificity and is involved in the assembly of the trans-envelope protein complex. The RND protein family was first described as a related group of bacterial transport proteins involved in heavy metal resistance ( $C$. metallidurans), nodulation (Mesorhizobium loti) and cell division (E. coli) (Saier et al. 1994). The RND protein is usually accompanied by the membrane fusion protein (MFP) (Saier et al. 1994) and outer membrane factor (OMF) (Paulsen et al. 1997; Johnson and Church 1999). OMF and MFP proteins have a rather static function during CBA-mediated transenvelope efflux. These three proteins form an efflux protein complex that may export its substrate from the cytoplasm, the cytoplasmic membrane or the periplasm across the outer membrane directly to the outside of the cell (Zgurskaya and Nikaido 1999a, 1999b; 2000a, 2000b). In bacteria and archaea, CBA transporters are involved in transport of heavy metals, hydrophobic compounds, amphiphiles, nodulation factors and proteins (Tseng et al. 1999). In addition, these transport systems could remove cations even before they have the opportunity to enter the cell and could mediate 10 further export of the cation that had been removed from the cytoplasm by other efflux systems (Nies 2003).

It is crucial to obtain valuable information not only about bacteria in heavy-metal contaminated soil but especially about genetic potential which they contain, and which enables them to survive in these harmful conditions. Thus, in our studies, we aimed to obtain new information not only about a newly isolated bacterium tentatively assigned to uncultured gammaproteobacteria from soil contaminated by different heavy metals, first of all by high nickel concentrations but also about its heavy-metal-resistance gene product which participate in bacterium protection against their deleterious effects on the cell.

\section{Materials and Methods}

\section{Isolation and cultivation of bacterial isolate MR-CH-I15-I}

Bacterium MR-CH-I15-I [KC809952] was isolated by diffusion chamber approach (Kaeberlein et al. 2002) with some modifications (Remenár et al. 2015) from farmland near the town of Sered' $\left(48^{\circ} 16^{\prime} 59^{\prime \prime} \mathrm{N}, 17^{\circ} 43^{\prime} 35^{\prime \prime} \mathrm{E}\right)$ in southwest Slovakia. The sampling site was situated near a dump containing heavy-metal-contaminated waste. Investigated field site contained high concentrations of nickel (2109 mg/kg), slightly above the natural occurrence of cobalt $(355 \mathrm{mg} / \mathrm{kg})$ and zinc $(177 \mathrm{mg} / \mathrm{kg})$, even too low concentration of iron $(35.75 \mathrm{mg} / \mathrm{kg})$ for a normal soil and not a toxic amount of copper $(32.2 \mathrm{mg} / \mathrm{kg})$ and cadmium $(<0.25 \mathrm{mg} / \mathrm{kg})$. The content of heavy metals in the soil sample was measured using an atomic absorption spectrometer (PerkinElmer model 403, USA) (Karelová et al. 2011). The site is according to environmental monitoring of Slovakia a part of strongly disturbed environment (Bohuš and Klinda 2010).

Bacterium MR-CH-I15-I was cultivated on LB (LuriaBertani) agar plates (HiMedia, India) aerobically at $30^{\circ} \mathrm{C}$ for $24 \mathrm{~h}$ and independently growing colonies were used for further analysis.

\section{Microscopy, morphology and the biochemically activity determination of the bacterium NM-CH-I15-I}

Microscopy, morphology and biochemical activity determination (by use of GEN III MicroPlate (Biolog, USA)) of the bacterium NM-CH-I15-I were realized by Czech Collection of Microorganisms (CCM), Masaryk University, Faculty of Science, Brno, Czech Republic.

\section{Heavy-metal resistance determination of the bacterium NM-CH-I15-I}

The heavy-metal resistance of the bacterium NM-CH-I15-I was tested on LB agar (HiMedia, India) by disc diffusion method with 5 heavy metals, nickel (Ni), cobalt (Co), zinc $(\mathrm{Zn})$, cadmium $(\mathrm{Cd})$ and copper $(\mathrm{Cu})$, at the concentrations of about 0 (as control), 10, 50, 100, 500 and $1000 \mathrm{mg} / \mathrm{ml}$ according to Hassen et al. (1998) with some modifications. The isolates were grown in LB in Erlenmeyer flasks placed in a rotary shaker $\left(200 \mathrm{rpm}\right.$, Biosan, Lithuania) at $30^{\circ} \mathrm{C}$. When cultures achieved an $\mathrm{OD}_{420}$ of 0.5 , cells were serially diluted to a final cell density of about $10^{7}-10^{8}$ cells $/ \mathrm{ml}$ and spread on LB agar. Then the discs with appropriate heavy metals and appropriate concentrations were spotted on agar plates and incubated $24 \mathrm{~h}$ at $30^{\circ} \mathrm{C}$. The heavy-metal resistance was measured by inhibitory zone creation of appropriate heavy metal discs.

\section{Antibiotic resistance determination of the bacterium NM-CH-I15-I}

Antibacterial susceptibility testing was carried out by disc diffusion method on Mueller-Hinton agar (HiMedia, India) with 10 antibiotics; $30 \mathrm{mg}$ of amoxicillin/clavulanic acid, $10 \mathrm{mg}$ of ampicillin, $5 \mathrm{mg}$ of ciprofloxacin, $30 \mathrm{mg}$ of chloramphenicol, $15 \mathrm{mg}$ of erythromycin, $120 \mathrm{mg}$ of gentamycin, $10 \mathrm{mg}$ of penicillin, $5 \mathrm{mg}$ of rifampicin, $30 \mathrm{mg}$ of tetracyclin and $30 \mathrm{mg}$ of vancomycin (Oxoid, UK). Fresh culture of the bacterium NM-CH-I15-I, grown in LB in Erlenmeyer flask placed in a rotary shaker (200 rpm, Biosan, Lithuania) $12 \mathrm{~h}$ at $30^{\circ} \mathrm{C}$, was diluted to $0.5 \mathrm{McF}$ arland (Bio Merieux $\mathrm{SA}$, France) and spread on Mueller-Hinton agar. Then the antibiotic discs were spotted on agar plates and incubated 
$12 \mathrm{~h}$ at $30^{\circ} \mathrm{C}$. The inhibition results were evaluated according to the break points recommended by the NCCLS antimicrobial susceptibility testing standards M2-A7 (NCCLS, 2000: Performance standards for antimicrobial disk susceptibility tests. Approved Standard. 7th ed. NCCLS document M2-A7, NCCLS, Wayne, Pa.).

\section{Antibacterial effect determination of the bacterium NM-CH-I15-I}

The antibacterial activity of the bacterium NM-CH-I15-I was tested against five Gram-positive (Arthrobacter sp. AK-5, Bacillus subtilis PY79, Brevibacterium flavum CCM 251, Lysinibacillus sp. AK-11, Streptomyces coelicolor M145), and five Gram-negative (Bacteroidetes sp. AK-13, Beta proteobacterium AK-23, E. coli, Ralstonia picketii MR-CH-I2, Stenotrophomonas chelatiphaga AK-32) bacterial strains (IMB SAS collection). Bacterium NM-CH-I15-I was grown in LB medium (HiMedia, India) in Erlenmeyer flask placed in a rotary shaker (200 rpm, Biosan, Lithuania) overnight at $30^{\circ} \mathrm{C}$, the culture was 10 -fold diluted in $10 \mathrm{mmol} / \mathrm{l}$ Tris- $\mathrm{HCl}$ ( $\mathrm{pH} 7.0$ ), and $5 \mathrm{ml}$ aliquots were spotted in triplicate onto the surface of a LB agar plate. The plates were incubated overnight at $30^{\circ} \mathrm{C}$, and then overlaid with $5 \mathrm{ml}$ of $\mathrm{LB}$ soft agar $(0.7 \%$ agar $)$ seeded with $0.1 \mathrm{ml}$ of an overnight culture of one of ten indicator strains. Plates were incubated for $12 \mathrm{~h}$ at $30^{\circ} \mathrm{C}$ and then checked for clear zones around the previously uncultured isolates.

\section{DNA extraction}

Bacterial DNA from bacterial NM-CH-I15-I cells was isolated using the DNeasy purification kit (Qiagen, Hilden, Germany) according to the manufacturer's instructions as described in Karelová et al. (2011). The resulting high-

Table 1. PCR conditions and PCR product sizes of $16 \mathrm{~S}$ rRNA (rDNA) and marker genes

\begin{tabular}{lccc}
\hline Amplified genes & $\mathrm{T}_{\mathrm{a}}\left({ }^{\circ} \mathrm{C}\right)$ & $\mathrm{t}_{\mathrm{P}}(\mathrm{s})$ & $\begin{array}{c}\text { PCR product } \\
\text { sizes }(\mathrm{bp})\end{array}$ \\
\hline 16S rRNA (rDNA) & 53.3 & 45 & 1,492 \\
\hline ampC & 50.5 & 26 & 839 \\
atpD & 52.8 & 27 & 900 \\
carA & 51.7 & 21 & 700 \\
gyrB & 58.0 & 33 & 1,100 \\
pyrH & 50.0 & 23 & 944 \\
recA & 50.5 & 18 & 850 \\
rpoA & 51.2 & 25 & 822 \\
rpoB & 50.5 & 25 & 813 \\
rpoD & 50.5 & 25 & 833 \\
\hline
\end{tabular}

$\mathrm{T}_{\mathrm{a}}$, anellation temperature; $\mathrm{t}_{\mathrm{B}}$ polymerization time. molecular-weight DNA was stored at $-20^{\circ} \mathrm{C}$ and was used as a template in appropriate PCR experiments.

\section{Detection of $16 S$ rRNA (16S rDNA) and 9 further marker genes used for bacterial identification}

DNA extracted from bacterium MR-CH-I15-I was used in PCR either with universal 16S rRNA gene primers (27F, $1492 \mathrm{R}$ ) or with appropriate bacterial primer sets for amplification either of 9 further marker gene fragments $(a m p C$, atpD, carA, gyr $\mathrm{B}, p y r \mathrm{H}, r e c \mathrm{~A}, r p o \mathrm{~A}, r p o \mathrm{~B}, r p o \mathrm{D}$ ) (Table $\mathrm{S} 1$ in Suppl. materials). Each $20 \mu \mathrm{l}$ reaction mixture contained $10 \mu \mathrm{l}$ Q5 Hot Start High-Fidelity 2' Master Mix (New England Biolabs, USA), $1 \mu \mathrm{l}(0.5 \mu \mathrm{M})$ of each primer, $1 \mu \mathrm{l}$ (10 ng) of the DNA template and $7 \mu \mathrm{l}$ of sterile deionised water. PCRs were performed in a thermal cycler (LabCycler, Goettingen, Germany). Reaction PCR conditions were, with exception of annelation temperatures and time of polymerisations, for all genes the same with the following cycling conditions: $30 \mathrm{~s}$ of denaturation at $98^{\circ} \mathrm{C}, 35$ cycles of $10 \mathrm{~s}$ at $98^{\circ} \mathrm{C}, 30 \mathrm{~s}$ of annelations, polymerisations at $72^{\circ} \mathrm{C}$, and a final cycle of extension at $72^{\circ} \mathrm{C}$ for $2 \mathrm{~min}$. However, annelation temperature and polymerisation time were for each individual gene different (Table 1). All PCR products were separated by electrophoresis in a $1 \%(\mathrm{w} / \mathrm{v})$ agarose gel (Merck, Germany) and stained with GelRed Nucleic Acid Gel Stain (Biotium, USA) and PCR product sizes are initiates in Table 1. DNA bands in appropriate sizes for individual genes were excised and purified using the QIAquick Gel Extraction Kit (Qiagen, Hilden, Germany) according to the manufacturer's instructions.

Detection of complete czcA-NM15I gene and its sequencing strategy

DNA extracted from bacterium MR-CH-I15-I was used in PCRs with subsequent primer sets (Fig. 1, Table S1):

i) $c z c \mathrm{~A}-\mathrm{NM} 15 \mathrm{I}$ gene fragment amplification and its subsequent sequencing with $14 \mathrm{nccF}$ primer located in early part of the conserved $c z c$ A gene from P. entomophila L48 [CT573326] and 2960nccR primer located in terminal part of earlier known nccA-like gene fragment, MRCH-I15-HMR-I [KF218088] from MR-CH-I15-I;

ii) sequencing of middle part of the amplicon created in point i) with $1692 \mathrm{nccF}$ and $2710 \mathrm{nccR}$ primers located in early and terminal parts of this amplicon, respectively;

iii) amplification of beginning of $c z c \mathrm{~A}-\mathrm{NM} 15 \mathrm{I}$ gene fragment and its subsequent sequencing with PF15I-Fb and PF15I-Rb primers located before $c z c \mathrm{~A}$ gene region from P. entomophila L48 [CT573326] and in known early part of the gene (amplicon created in point $i)$ ), respectively; 
Pseudomonas entomophila str. L48 [CT573326]

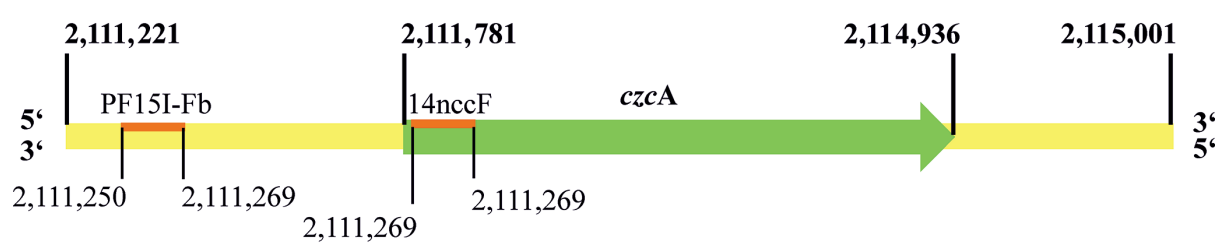

Pseudomonas putida str. NM-CH-I15-I [MG967453]

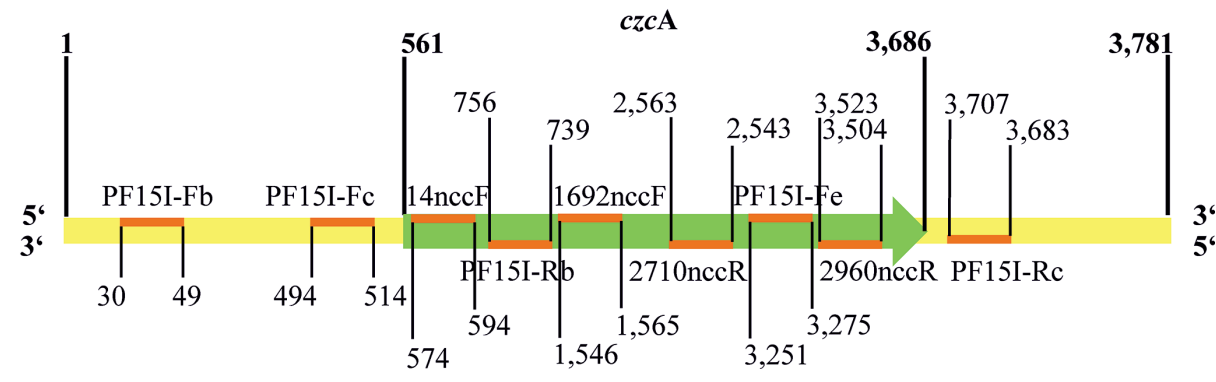

Figure 1. The whole $c z c \mathrm{~A}-\mathrm{NM} 15 \mathrm{I}$ [MK704499] gene detection and sequencing strategy of $P$. putida strain NM-CH-I15-I. Numbers in bold 3، indicate positions of the $c z c \mathrm{~A}$ or $c z c \mathrm{~A}$ NM15I genes (green arrow) and they neighbourhood areas (yellow arrow) on chromosome in the Pseudomonas entomophila str. L48 [CT573326] or on PCR products in the P. putida NMCH-I15-I [MG967453] numbering systems, respectively; orange short lines and numbers in normal indicate positions of appropriate primers on the $c z c \mathrm{~A}$ or $c z c \mathrm{~A}-\mathrm{NM} 15 \mathrm{I}$ genes and they 3، neighbourhood areas, respectively. 5' (See paragraph "Detection of complete czcA-NM15I gene and its sequencing strategy" and Table S1 for detail). (See online version for color figure). iv) amplification of terminal part of $c z c \mathrm{~A}-\mathrm{NM} 15 \mathrm{I}$ gene fragment and its subsequent sequencing with use of one primer, PF15I-Fe located in earlier known terminal part of the gene;

v) amplification of full length of $c z c \mathrm{~A}-\mathrm{NM} 15 \mathrm{I}$ gene with PF15IFc and PF15I-Rc primers located before and over of the earlier known $c z c \mathrm{~A}-\mathrm{NM} 15 \mathrm{I}$ gene sequence from P. putida NM-CH-I15-I [MG967453], respectively.

Each $20 \mu \mathrm{l}$ reaction mixture contained $10 \mu \mathrm{l}$ Q 5 Hot Start High-Fidelity 2' Master Mix (New England Biolabs, USA), $1 \mu \mathrm{l}(0.5 \mu \mathrm{M})$ of each primer (Table S1), $1 \mu \mathrm{l}(10 \mathrm{ng})$ of the DNA template and $7 \mu \mathrm{l}$ of sterile deionised water. PCRs were performed in a thermal cycler (LabCycler, Goettingen, Germany). Reaction PCR conditions were, with exception of amplification with use of one primer, for all gene fragments the same with the following cycling conditions: $30 \mathrm{~s}$ of denaturation at $98^{\circ} \mathrm{C}, 35 \mathrm{cycles}$ of $10 \mathrm{~s}$ at $98^{\circ} \mathrm{C}, 30 \mathrm{~s}$ at $55.3^{\circ} \mathrm{C}$ (i, ii), $46.3^{\circ} \mathrm{C}($ iii $)$ or $49.5^{\circ} \mathrm{C}(v), 1 \mathrm{~min} 30 \mathrm{~s}(i), 30 \mathrm{~s}(i i)$, $22 \mathrm{~s} \mathrm{(iii)} \mathrm{or} 1 \mathrm{~min} 37 \mathrm{~s}(v)$ at $72^{\circ} \mathrm{C}$, and a final cycle of extension at $72^{\circ} \mathrm{C}$ for $2 \mathrm{~min}$. All PCR products were separated by electrophoresis in a $1 \%(\mathrm{w} / \mathrm{v})$ agarose gel (Merck, Germany) and stained with GelRed Nucleic Acid Gel Stain (Biotium, USA). PCR product sizes, approximately 2,946, 1,018, 727 or 3,214 bp in size for (i), (ii), (iii) and ( $v$ ) gene fragments respectively, were excised and purified using the QIAquick Gel Extraction Kit (Qiagen, Hilden, Germany) according to the manufacturer's instructions.

In PCR with one gene primer (iv), $20 \mu$ reaction mixture contained $10 \mu \mathrm{l}$ Q5 Hot Start High-Fidelity 2' Master Mix (New England Biolabs, USA), $1 \mu \mathrm{l}(0.5 \mu \mathrm{M})$ of PF15I-Fe primer (Table S1), $1 \mu \mathrm{l}(10 \mathrm{ng}$ ) of the DNA template and $8 \mu \mathrm{l}$ of sterile deionised water. PCRs were performed in a thermal cycler (LabCycler, Goettingen, Germany) with the following cycling conditions: $30 \mathrm{~s}$ of denaturation at $98^{\circ} \mathrm{C}$, the first 29 cycles of $10 \mathrm{~s}$ at $98^{\circ} \mathrm{C}, 30 \mathrm{~s}$ at $51^{\circ} \mathrm{C}, 30 \mathrm{~s}$ at $72^{\circ} \mathrm{C}$ followed by repeated $30 \mathrm{~s}$ of denaturation at $98^{\circ} \mathrm{C}$, the second 29 cycles of $10 \mathrm{~s}$ at $98^{\circ} \mathrm{C}, 30 \mathrm{~s}$ at $40^{\circ} \mathrm{C}, 30 \mathrm{~s}$ at $72^{\circ} \mathrm{C}$ followed by repeated $30 \mathrm{~s}$ of denaturation at $98^{\circ} \mathrm{C}$, the third 29 cycles of $10 \mathrm{~s}$ at $98^{\circ} \mathrm{C}, 30 \mathrm{~s}$ at $51^{\circ} \mathrm{C}, 30 \mathrm{~s}$ at $72^{\circ} \mathrm{C}$ followed by a final cycle of extension at $72^{\circ} \mathrm{C}$ for $2 \mathrm{~min}$. The PCR product was separated by electrophoresis in a $1 \%(\mathrm{w} / \mathrm{v})$ agarose gel (Merck, Germany) and stained with GelRed Nucleic Acid Gel Stain (Biotium, USA). DNA band approximately $1,200 \mathrm{bp}$ in size was excised and purified using the QIAquick Gel Extraction Kit (Qiagen, Hilden, Germany) according to the manufacturer's instructions.

\section{Sequencing of $16 S$ rRNA (16S rDNA), 9 further marker genes and czcA-NM15I amplicons}

Subsamples of either purified 16S rRNA (16S rDNA), 9 further marker genes (Table S1) or all $c z c$ A-NM15I amplicons from isolate were sequenced by GATC Biotech, Constance, Germany.

\section{Bacterial strain and czcA-NM15I gene product identifications and phylogenetic analysis}

Bacterial strain identification, identification of complete $c z c \mathrm{~A}-\mathrm{NM} 15 \mathrm{I}$ gene products and phylogenetic analysis were performed as described in Karelová et al. (2011) with following modifications: multiple sequence alignments and phylogenetic trees were constructed with the MEGA software (version 6, Tamura et al. 2011). Maximum likelihood method with 100 bootstrap replications was chosen with Tamura-Nei model of substitutions and the resulting tree was presented with the Tree Explorer of the MEGA package. 
Bacterial cells preparation for czcA-NM15I gene expression analysis and total RNA isolation and purification

Bacterial culture $P$. putida NM-CH-I15-I was grown aerobically in liquid LB medium in Erlenmeyer flasks in a rotary shaker $\left(200 \mathrm{rpm}\right.$, Biosan, Lithuania) at $30^{\circ} \mathrm{C}$. When cultures reached an optical density at $420 \mathrm{~nm}\left(\mathrm{OD}_{420}\right)$ of 0.5 , five heavy metals were added to a previously optimized final concentration of $100 \mu \mathrm{g} / \mathrm{ml} \mathrm{Ni}^{2+}, 25$ and $50 \mu \mathrm{g} / \mathrm{ml}$ $\mathrm{Cd}^{2+}, 25$ and $50 \mu \mathrm{g} / \mathrm{ml} \mathrm{Zn}^{2+}, 10$ and $50 \mu \mathrm{g} / \mathrm{ml} \mathrm{Co}{ }^{2+}$ and $50 \mu \mathrm{g} / \mathrm{ml} \mathrm{Cu}^{2+}$, respectively. Appropriate aliquots of bacterial cultures were withdrawn from culture either before heavy metals addition (control sample) or $45 \mathrm{~min}$ after $\mathrm{Ni}$ $(100 \mu \mathrm{g} / \mathrm{ml})$, Cd and $\mathrm{Zn}(25 \mu \mathrm{g} / \mathrm{ml})$, Co $(10 \mu \mathrm{g} / \mathrm{ml})$ and $\mathrm{Cu}(50 \mu \mathrm{g} / \mathrm{ml})$ or $60 \mathrm{~min}$ after $\mathrm{Cd}$, Co and $\mathrm{Zn}(50 \mu \mathrm{g} / \mathrm{ml})$ additions, respectively.

Total RNA from bacterial cells was isolated and purified using the NucleoSpin RNA (Macherey-Nagel, Nemecko) according to the manufacturer's instructions. Concentrations and purity of isolated RNA were measured by NanoDrop 2000 (ThermoScientific, Wilmington, USA).

\section{Reverse-Transcription Quantitative Real-time PCR (RT-qPCR)}

Isolated and purified RNA from bacterium $P$. putida NM$\mathrm{CH}-\mathrm{I} 15-\mathrm{I}$ was used as template into gene expression analyses by RT-qPCR with relative quantification normalised to endogenous reference gene $g d h \mathrm{~A}$. The relative quantification (RQ) of $c z c \mathrm{~A}-\mathrm{NM} 15 \mathrm{I}$ gene was determined after heavy metal impacts related to control (untreated) sample. For RQ calculation was used the $2^{-\Delta \Delta C q}$ methods (Bustin et al. 2009) named also as $2^{-\Delta \Delta \mathrm{Ct}}$ (Livak and Schmittgen 2001).

Each $20 \mu \mathrm{l}$ reaction mixture contained $11.5 \mu$ Brilliant III Ultra-Fast SYBR ${ }^{\oplus}$ Green QRT-PCR Master Mix (Agilent Technologies, USA), $1 \mu \mathrm{l}(0.5 \mu \mathrm{M})$ of each primer (PF15IRT-F and PF15I-RT-R for czcA-NM15I gene and PF15IgdhA-RT-F and PF15I-gdhA-RT-R for housekeeping gdhA gene, respectively (Table S1)), $2 \mu \mathrm{l}$ RNA (10 ng/ $\mu \mathrm{l})$ and $4.5 \mu \mathrm{l}$ sterile deionised water.

Reaction was performed in a thermal cycler AriaMx Realtime PCR System (Agilent Technologies, USA) with the following programme: $1^{\prime} 10 \mathrm{~min}$ at $50^{\circ} \mathrm{C}, 1^{\prime} 3 \mathrm{~min}$ at $95^{\circ} \mathrm{C}$, $40 \mathrm{cycles}$ of $5 \mathrm{~s}$ at $95^{\circ} \mathrm{C}, 15 \mathrm{~s}$ at $60^{\circ} \mathrm{C}$ and a final analysis of the "melting curve" - temperature decreased from $95^{\circ} \mathrm{C}$ to $65^{\circ} \mathrm{C}$ and subsequently increased from $65^{\circ} \mathrm{C}$ to $95^{\circ} \mathrm{C}$ by $0.5^{\circ} \mathrm{C}$ every $5 \mathrm{~s}$.

Results were evaluated using AriaMx Software v1.0 and the obtained Cq values were used for calculation of difference in $c z c \mathrm{~A}-\mathrm{NM} 15 \mathrm{I}$ gene expression in control sample and in the presence of individual heavy metals normalised on reference gene $g d h \mathrm{~A}$ according to subsequent formula:

$\Delta \mathrm{Cq}=\mathrm{Cq}_{\text {gene }}-\mathrm{Cq}_{\mathrm{ref}}$,
$\Delta \Delta \mathrm{Cq}=\Delta \mathrm{Cq}_{\text {sample }}-\Delta \mathrm{Cq} \mathrm{q}_{\text {control }}$, $\mathrm{RQ}=2^{-\Delta \Delta \mathrm{Cq}}$,

where $\mathrm{Cq}_{\text {gene }} / \mathrm{Cq}_{\text {ref }}$ is value averages $\mathrm{Cq} 1-\mathrm{Cq} 3$ for monitored/reference gene; $\Delta \mathrm{Cq}$ is the differences of fluorescence level of monitored gene samples and fluorescence of reference gene; $\Delta \Delta \mathrm{Cq}$ is the differences of fluorescence level changes of induced (by heavy metal) and control (noninduced) sample.

\section{The synthetic czcA-NM15I gene preparation}

The synthetic variant of $c z c \mathrm{~A}-\mathrm{NM} 15 \mathrm{I}$ gene was prepared by General Biosystems, Inc., USA via BioCat, Heidelberg, Germany. As a result was synthetic $c z c \mathrm{~A}-\mathrm{NM} 15 \mathrm{I}$ gene cloned in pET-21a(+) plasmid (Merck, USA).

\section{Transformation of E. coli competent cells by plasmid pET-21a(+)}

pET-21a(+) plasmid carrying synthetic czcA-NM15I gene (General Biosystems, Inc., USA) was transformed to E. coli BL21 (DE3) (New England BioLabs, USA) competent cells according to the manufacturer's instructions of New England BioLabs (USA) or Promega (USA), respectively.

The expression of CzcA-NM15I protein with IPTG induction in E. coli BL21 (DE3) cells carrying synthetic gene on pET21a(+) plasmid

The expression of CzcA-NM15I protein was carried out during growth of bacterium E. coli BL21 (DE3) carrying synthetic $c z c \mathrm{~A}-\mathrm{NM} 15 \mathrm{I}$ gene on pET21a(+) plasmid with IPTG addition to a final concentration of $1 \mathrm{mM}$. Bacterial culture E. coli BL21 (DE3) was grown aerobically in liquid LB medium with ampicillin $(100 \mathrm{mg} / \mathrm{ml})$ addition in Erlenmeyer flasks in a rotary shaker $(200 \mathrm{rpm}$, Biosan, Lithuania) at $37^{\circ} \mathrm{C}$. When cultures reached an optical density at $600 \mathrm{~nm}\left(\mathrm{OD}_{600}\right)$ of $0.6,50 \mathrm{ml}$ aliquots of bacterial cultures in two times were withdrawn from culture and immediately was added IPTG (1 mM). Bacterial suspensions were centrifuged $\left(4,000 \mathrm{rpm}, 20 \mathrm{~min}\right.$ at $\left.4^{\circ} \mathrm{C}\right) 3 \mathrm{~h}$ after IPTG ( $1 \mathrm{mM})$ addition and acquired sediment was used for further protein analysis.

\section{The protein extract analysis}

After sonication (100 s cycle (5 s sonication, 25 s cooling on ice), (Soniprep 150 cell disrupter, MSE, UK), the protein extracts were purified by use of Ni-column, HisTrap HP, $1 \mathrm{ml}$ (GE Healthcare UK Limited, UK) either under denaturation (with $8 \mathrm{M}$ urea addition) or non-denaturation (without urea addition) conditions according to the manufacturer's instructions. Obtained protein eluates were subsequently analysed 
by electrophoresis according to the methods of Laemmli (1970) using a Mini-Protean apparatus (BioRad, USA) with following modifications: an equal volume of SDS-PAGE sample buffer ( $5 \mathrm{ml}$ of $350 \mathrm{mMDTT}$ and $95 \mathrm{ml}$ of $2^{\prime}$ Laemmli buffer: $250 \mathrm{mM}$ Tris- $\mathrm{HCl}, \mathrm{pH} 6.8,25 \%$ glycerol, $2 \%$ SDS and $0.01 \%(\mathrm{w} / \mathrm{v})$ bromophenol blue) was added to the $10 \mathrm{ml}$ of protein eluate and samples were incubated in thermoblock (Eppendorf, Germany) $10 \mathrm{~min}$ at $95^{\circ} \mathrm{C}$. The proteins were subsequently separated through 4-20\% MiniProtean TGX Precast protein gels (Bio-Rad, USA) in electrophoretic 1' TRIS/Glicine/SDS buffer (BioRad, USA) at $216 \mathrm{~V}$ and $70 \mathrm{~A}$. Each gel was prepared in duplicate and in one of them the separated proteins were stained by Coomassie brilliant blue R-250 (Laemmli 1970). The second gel was used for Western immunoblot assays.

\section{Western immunoblot assays (Semi-dry)}

After electrophoresis, the gels, nitrocellulose membranes (Amersham, UK) and blotting paper Whatman 3MM (Merck, USA) were soaked in 1' Blotting buffer (10\% (v/v) 10' Blotting buffer (500 mM Tris-base, $390 \mathrm{mM}$ glycine, 0.039\% SDS), $20 \%$ (v/v) methanol) for $20 \mathrm{~min}$. The gels, sandwiched between sheets of nitrocellulose membrane and several sheets of blotting paper (Whatman 3MM), were assembled into a blotting apparatus (Biometra Fastblot, Germany) and electroeluted for $90 \mathrm{~min}$ at $200 \mathrm{~mA}$. Immunoblot assay was done as follows: The nitrocellulose membranes were washed with sterile deionised $\mathrm{H}_{2} \mathrm{O}$ and soaked in TBS buffer $(10 \mathrm{mM}$ Tris-HCl pH 8.0; $150 \mathrm{mM} \mathrm{NaCl}$ ) for 20 min. Subsequently, membranes were transferred into blocking buffer (TBS with 2\% BSA (Bovine Serum Albumin) (Sigma-Aldrich, USA)) for $2 \mathrm{~h}$. In next step, the membranes were probed with a $100 \mathrm{ng} / \mathrm{ml}$ of a monoclonal PentaxHis Antibody (Qiagen, Germany) as a primary antibody in TBST buffer (TBS buffer + Tween 20) with $2 \%$ BSA overnight under slow agitation at $4^{\circ} \mathrm{C}$. After overnight incubation, the membranes were washed 7 min 3 times with TBST buffer with $2 \%$ BSA. In next step, the membranes were probed with a 1:15,000 dilution of a Goat Anti-Mouse IgG-AP conjugated with alkaline phosphatase (Sigma-Aldrich, USA) as a secondary antibody in TBST buffer with 2\% BSA $1 \mathrm{~h}$ under slow agitation and subsequently washed 7 min 3 times with TBST buffer. At the end, the membranes were washed by the buffer with alkaline phosphatase (0.1 M Tris- $\mathrm{HCl} \mathrm{pH}$ 9.5; $0.1 \mathrm{M} \mathrm{NaCl}$; $0.05 \mathrm{M} \mathrm{MgCl}_{2} \cdot 6 \mathrm{H}_{2} \mathrm{O}$ ). In last step, a coloured detection of AP with $0.3 \%$ BCIP/0.6\% NBT Color Development Substrate (Promega, USA) in a solution of alkaline phosphatase was used under dark membrane incubations without agitation and after cca 5 min coloured bands on the membranes were observed. The reaction was stopped via membrane washing of intense water flow and membranes were transferred on Whatman 3 MM paper (Merck, USA) and dried on air.
The detection of functionally important amino acids involved in heavy metal transports in CzcA-NM15I protein

According to known sequence of $c z c \mathrm{~A}-\mathrm{NM} 15 \mathrm{I}$ and its translation product, respectively, the literature sources were searched for evolutionary closely related genes to $c z c \mathrm{~A}$ NM15I and they products participated in resistance against heavy metals. The accent was aimed to gene products with known not only their functions but also their molecular characteristics. One of thus characterised protein was found ZneA from Cupriavidus metallidurans $\mathrm{CH} 34$ (Pak et al. 2013) and a second protein CusA from E. coli (Franke et al. 2003; $\mathrm{Su}$ et al. 2012). These protein sequences were used as sources for alignment preparations using MEGA software (version 6, Tamura et al. 2011). The amino acid positions involved in heavy metal cation transports in ZneA and CusA protein sequences respectively, were checked with same amino acid positions in CzcA-NM15I protein sequence. The alignments were documented by use of GeneDoc MFC Application software (version 2.7.0.0.).

\section{Design of homology model of CzcA-NM15I protein from P. putida NM-CH-I15-I}

The homology three dimensional model of CzcA-NM15I protein was constructed with Phyre ${ }^{2}$ software (http:// www.sbg.bio.ic.ac.uk/phyre2/webscripts/jobmonitor. cgi?jobid=21d5d646db823a7) (Kelley et al. 2015) and was presented with ViewerLite software.

\section{Nucleotide sequence accession numbers}

The sequences generated in this study have been deposited in the GenBank database under accession number MG967453 for bacterial isolate NM-CH-I15-I 16S rRNA (16S rDNA) gene, from MK690197 to MK690205 for bacterial isolate NM-CH-I15-I marker genes and MK704499 for complete $c z c \mathrm{~A}-\mathrm{NM} 15 \mathrm{I}$ gene of bacterial isolate NM-CH-I15-I.

\section{Results and Discussion}

\section{Identification of the specific heavy-metal resistance bacterium}

To identify unequivocally previously isolated heavymetal resistant bacterium a phylogenetic analysis was performed of almost the whole (1,1492 bp) 16S rRNA (16S rDNA) sequence and sequences for products of nine other marker genes $(\operatorname{amp} \mathrm{C}, \operatorname{at} p \mathrm{D}, \operatorname{car} \mathrm{A}, g y r \mathrm{~B}, p y r \mathrm{H}, r e c \mathrm{~A}$, rpo $\mathrm{A}, r p o \mathrm{~B}, r p o \mathrm{D})$. These products were in last decades used as phylogenetic molecular markers in taxonomic studies (Case et al. 2007; Liu et al. 2012; Vinje et al. 2014). 
The results from these analyses showed that the bacterial isolate was assigned on the basis of $16 \mathrm{~S}$ rRNA and eight other marker product genes either to $P$. putida or to relevant individual marker product genes from $P$. putida with similarities from $97 \%$ to $100 \%$, respectively (Fig. 2, Fig. S1 in Supplementary materials). The exception has posed ampC product gene which was assigned to AmpC from $P$. parafulva with $75 \%$ similarity (Fig. S1A). This discrepancy could be related to grouping of such type strains as $P$. fulva, $P$. parafulva and $P$. cremoricolorata into phylogenetic branch of $P$. putida and they are referred to the representatives of $P$. fluorescens lineage (Peña et al. 2016). Besides of 16 S rRNA genes which are commonly used for descriptions and identifications of new and unknown bacterial species by phylogenetic analysis, for accurate taxonomic assignment of bacteria to appropriate taxa is inevitable to monitor the results of phylogeny reconstructed according to different genes because issues like convergence, long-branch attraction, and hidden paralog can lead to incorrect tree inference (Maddison 1997; Lang et al. 2013). For example, the rpoB gene encoded b-subunit of RNA-polymerase presents one of appropriate genes for taxonomic assignment of bacteria (Case et al. 2007). Thus, on this basis, bacterial isolate was identified as $P$. putida strain NM-CH-I15-I [MG967453].

This bacterium was firstly found inside of bacterial community isolated by using diffusion chamber methods from strongly disturbed environment mainly by high nickel concentrations in southwest Slovakia, and marked as MR-CH-I15-I [KC809952] and tentatively assigned on the basis of relatively short (685 bp) $16 \mathrm{~S}$ rRNA ( $16 \mathrm{~S}$ rDNA) to Uncultured bacterial clone HelTree3-110 [JN05267] on a gProteobacteria branch of phylogenetic tree (Remenár et al. 2015). According to the origin of the bacterium, its assignment to the species $P$. putida is not surprising because this saprophytic bacterial species is widespread and it is known not only for the ability to degrade different biogenic compounds and xenobiotics but also tolerances against heavy metal ions (Hu and Zhao 2007; Özen and Ussery 2012). In fact, a lot of strains of the species $P$. putida dispose with broad spectrum of metabolic features and a lot of isolates with unique phenotypes (Wu et al. 2010). They are adaptable with great metabolic versatileness, consequently the representatives of this species are able to colonise not only

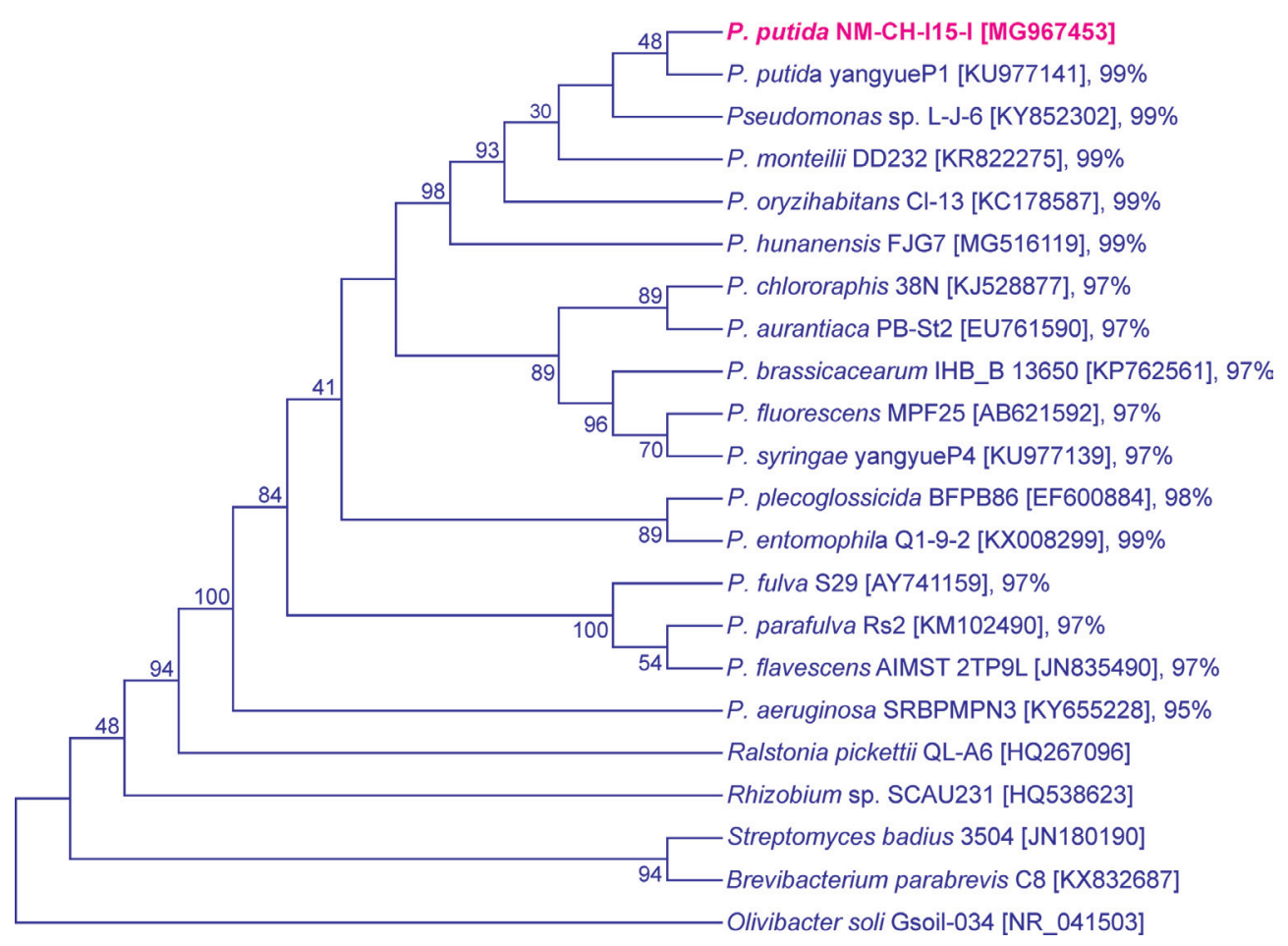

Figure 2. Unrooted phylogenetic tree obtained by the maximum likelihood method with 100 bootstrap replications showing phylogeny of $16 \mathrm{~S}$ rRNA (16S rDNA) gene sequences of the bacterium P. putida NM-CH-I15-I (in pink bold) and members of the genus Pseudomonas. Ralstonia pickettii QL-A6 [HQ267096], Rhizobium sp. SCAU231 [HQ538623], Streptomyces badius strain 3504 [JN180190], Brevibacterium parabrevis C8 [KX832687] and Olivibacter soli strain Gsoil 034 [NR_041503] were used as outgroup. Numbers in square brackets indicate the GenBank accession number and similarity to closest relative is shown after the bacteria designation. Sequences of about 1,492 bp in length were aligned with ClustalW. (See online version for color figure). 
soils with appropriate conditions for growth but they are able to survive in extreme environmental conditions, such as deserted soils or soils contaminated by different kinds of antibiotics and heavy metals (Ramette and Tiedje 2007).

\section{Microscopy, cell morphologies and biochemical analysis of the bacterium P. putida NM-CH-I15-I}

Microscopy of Gram stained bacterium NM-CH-I15-I showed that bacterial cells have comprised short Gramnegative rods sorted either single, in clusters or palisades. Bacterium growing on solid cultivation medium has formed round, smooth, bright, convex colonies with a continuous edging of about $1-2 \mathrm{~mm}$ in size and light beige coloured. These morphologic characteristics are typical for bacterial species P. putida (Stanier et al. 1966; Özen and Ussery 2012).

Biochemical activity of the bacterium was determined by use of GEN III MicroPlate (Biolog, USA) and analyses were realised via Czech Collection of Microorganisms (Brno, Czech Republic). The results from biochemical analyses showed that bacterium was catalase, glucose oxidation, mobility and oxidase positive and negative to glucose fermentation. In addition, bacterium was tolerant against 16 and sensitive to 7 different substrates, it did not hydrolyse 3 , utilised 27 and did not utilised 41 kinds of substrates tested (Table 2). All these analyses were realized via Czech Collection of Microorganisms (Brno, Czech Republic).

On the base of biochemical characteristics this bacterium was assigned to $P$. plecoglossicida with ID 0.965 . This discrepancy between biochemical and molecular identification of bacterium could be related to its nature as an environmental strain isolated from heavy metal contaminated soil. Identifications of bacteria isolated from environmental samples based on their biochemical properties can be problematic because some of important biochemical features could be overlapped by different things and thus the identification could be inaccurate (Chovanová et al. 2004). The second reason of this discrepancy could be related to the great degree of the nearest neighbours of both bacterial species and P. plecoglossicida is located on the phylogenetic branch of P. putida (Mao et al. 2013). It seems that small distinctions between species are detected earlier by molecular based methods that biochemical one.

\section{Heavy-metal resistance of the P. putida NM-CH-I15-I}

The bacterium P. putida NM-CH-I15-I was tested for it resistance against 5 heavy metals $(\mathrm{Ni}, \mathrm{Cd}, \mathrm{Co}, \mathrm{Zn}, \mathrm{Cu})$ in 5 different concentrations (10,50, 100, 500, 1,000 $\mu \mathrm{g} / \mathrm{disc})$ by disc diffusion methods. The results showed that in general, the bacterium was resistant to all tested metals, but the level of resistance against individual metals differed. However, the bacterium showed the highest level of resistance against nickel and copper (resistance against 100 and intermediate resistance against $500 \mu \mathrm{g}$ of these two metals per discs, respectively), a little lower against zinc (resistance against $50 \mu \mathrm{g}$ per disc) and the lowest against cobalt and cadmium (intermediate resistance against $50 \mu \mathrm{g}$ of these two metals per disc). On the other hand, this bacterium was sensitive to concentration $1,000 \mu \mathrm{g} / \mathrm{disc}$ of all metals tested (Table 3).

Table 2. Biochemical analysis of the bacterium P. putida NM-CH-I15-I by use of GEN III MicroPlate (Biolog, USA)

\begin{tabular}{|c|c|}
\hline $\begin{array}{l}\text { Tested } \\
\text { characteristics }\end{array}$ & Test results \\
\hline Tolerance & $\begin{array}{l}\text { Growth at: } \mathrm{pH} 6 \text {; in presence of: } 1 \% \mathrm{NaCl} ; 1 \% \text { sodium lactate; troleandomycin; lincomycin; vancomycin; nalidixic } \\
\text { acid }( \pm) \text {; aztreonam }( \pm) \text {; rifamycin SV; guanidine } \mathrm{HCl} \text {; tetrazolium violet; lithium chloride; } \mathrm{D} \text {-serine }( \pm) \text {; niaprol 4; } \\
\text { tetrazolium blue; potassium tellurite }\end{array}$ \\
\hline \multirow{3}{*}{$\begin{array}{l}\text { Sensitivity } \\
\text { Hydrolysis }\end{array}$} & Growth at: $\mathrm{pH} 5$; in presence of: $4 \% \mathrm{NaCl} ; 8 \% \mathrm{NaCl}$; fusidic acid; minocycline; sodium butyrate; sodium bromate \\
\hline & Do not hydrolyze: gelatin, tween 40 , pectin \\
\hline & $\begin{array}{l}\text { Utilise: a-D-glucose, D-mannose }( \pm) \text {, g-amino-butyric acid, D-fructose }( \pm), \mathrm{L} \text {-alanine, L-arginine, D-gluconic acid, } \\
\text { L-lactic acid, b-hydroxy-D, L-butyric acid, glycerol }( \pm) \text {, L-aspartic acid, citric acid, D-fucose }( \pm) \text {, L-glutamic acid, } \\
\text { glucuronamide, a-keto glutaric acid, L-fucose }( \pm), \mathrm{D} \text {-fructose-6-PO4, L-histidine }(\mathrm{Mm}), \text { mucic acid, propionic acid, } \\
\text { quinic acid, L-malic acid, acetic acid, D-serine, L-serine, D-saccharic acid }(\mathrm{Mm})\end{array}$ \\
\hline Utilization & $\begin{array}{l}\text { Do not utilise: dextrin, D-maltose, D-trehalose, D-cellobiose, gentiobiose, sucrose, D-turanose, stachyose, D-raffinose, } \\
\text { a-D-lactose, D-melibiose, b-methyl-D-glucoside, D-salicin, N-acetyl-D-glucosamine, N-acetyl-b-D-mannosamine, } \\
\text { N-acetyl-D-galactosamine, N-acetyl neuraminic acid, D-galactose, 3-methyl glucose, L-rhamnose, inosine, D-sorbitol, } \\
\text { D-mannitol, D-arabitol, myo-inositol, D-glucose-6-PO4, D-aspartic acid, glycyl-L-proline, L-pyroglutamic acid, } \\
\text { D-galacturonic acid, D-galactonic acid lactone, D-glucuronic acid, p-hydroxy phenylacetic acid, methyl pyruvate, } \\
\text { D-lactic acid methyl ester, D-malic acid, bromo-succinic acid, a-hydroxy-butyric acid, a-keto butyric acid, acetoacetic } \\
\text { acid, formic acid }\end{array}$ \\
\hline
\end{tabular}

Note: Analyses were realised via Czech Collection of Microorganisms (Brno, Czech Republic). 
Table 3. Heavy-metal resistance of the bacterium P. putida NM$\mathrm{CH}-\mathrm{I} 15-\mathrm{I}$

\begin{tabular}{lccccc}
\hline \multirow{2}{*}{$\begin{array}{l}\text { Heavy } \\
\text { metal }\end{array}$} & \multicolumn{5}{c}{ Heavy-metal concentrations (mg/disc) } \\
\cline { 2 - 6 } & 10 & 50 & 100 & 500 & 1,000 \\
\hline $\mathrm{Ni}$ & $\mathrm{R}(13)$ & $\mathrm{R}(13)$ & $\mathrm{R}(13)$ & $\mathrm{I}(18)$ & $\mathrm{S}(30)$ \\
$\mathrm{Cd}$ & $\mathrm{R}(13)$ & $\mathrm{I}(17)$ & $\mathrm{S}(20)$ & $\mathrm{S}(25)$ & $\mathrm{S}(43)$ \\
$\mathrm{Co}$ & $\mathrm{R}(13)$ & $\mathrm{I}(18)$ & $\mathrm{S}(22)$ & $\mathrm{S}(29)$ & $\mathrm{S}(37)$ \\
$\mathrm{Zn}$ & $\mathrm{R}(13)$ & $\mathrm{R}(13)$ & $\mathrm{I}(16)$ & $\mathrm{S}(21)$ & $\mathrm{S}(31)$ \\
$\mathrm{Cu}$ & $\mathrm{R}(13)$ & $\mathrm{R}(13)$ & $\mathrm{R}(13)$ & $\mathrm{I}(15)$ & $\mathrm{S}(30)$ \\
\hline
\end{tabular}

$\mathrm{R}$, resistance; $\mathrm{I}$, intermediate resistance; $\mathrm{S}$, sensitive. The numbers in parenthesis indicate the inhibitive zones (in $\mathrm{mm}$ ).

The detected highest level of bacterial resistance against nickel and copper was possible considering that the bacterium was primarily isolated from soil contaminated mainly by high nickel $(2,109 \mathrm{mg} / \mathrm{kg})$ and relative high copper $(32,2 \mathrm{mg} / \mathrm{kg})$ concentrations. In addition, lower bacterial resistance against cadmium could be explained by trace amount of this metal (less than $0.25 \mathrm{mg} / \mathrm{kg}$ ) in soil. On the other hand, relative lower bacterial resistance against cobalt and zinc did not correlate with relative high cobalt $(355 \mathrm{mg} / \mathrm{kg})$ and zinc $(177 \mathrm{mg} / \mathrm{kg})$ concentrations in soil sample (Karelová et al. 2011). Karelová et al. (2011), Harichová et al. (2012) and Remenár et al. (2015) state similar results for bacterial isolates of different taxon from same sampling site. In addition, Muñoz et al. (2012) have found out that inside of bacterial assemblages predominated tolerant and resistant bacteria against heavy metals as a result of soil contaminations by heavy metals. The results from these analyses suggested that the determined resistance of bacterial strain P. putida NM-CH-I15-I against heavy metals could be related to its defence mechanisms against these metals protected by appropriate/appropriates determinant/ determinants resistance against heavy metals.

\section{Resistance against antibiotics of the bacterium P. putida $\mathrm{NM}-\mathrm{CH}-\mathrm{I1}$-I}

It is generally known that inside of natural bacterial assemblages the heavy-metal resistance and resistance against antibiotics are often carried on the same bacterial plasmids or transposons (Vranes et al. 1994; Mcintosh et al. 2008; Lima et al. 2012). In addition, the bacterial adaptive flexibility in large measure contributes to constitution of bacterial resistance to the antibiotics what cause the breaking of present antimicrobial therapies (Meireles et al. 2013). Therefore the bacterium $P$. putida NM-CH-I15-I was also tested for its resistance against some kinds of antibiotics (ATBs). The results revealed that the bacterium $P$. putida NM-CH-I15-I carried resistance against 7 of 10 tested antibiotics belonging to different groups. It didn't carry resistance against Ciprofloxacin, Gentamycin and Tetracycline, respectively (Table 4). Remenár et al. (2015) have stated similar results who found that majority of g-Proteobacteria representatives isolated from same locality were multiresistant but all were sensitive to Ciprofloxacin and Gentamycin. These authors also stated that representatives of g-Proteobacteria are in generally more resistant against different kinds of antibiotics compare to b-Proteobacteria representatives. Similarly, among isolates collected from all the world farms predominated Gramnegative bacteria with very low sensitivities against $\beta$-lactam antibiotics which belonged to the Pseudomonadaceae family with predominance (92\%) of P. putida (Meireles et al. 2013). These results suggested that the multiple antibiotic resistances of the bacterial strain P. putida NM-CH-I15-I could be obtained within the frame of the spread among natural bacterial consortia.

\section{Antibacterial effects of the bacterium P. putida NM-CH-I15-I}

Some of the g-Proteobacteria representatives, mainly of Pseudomonads, are known for their antibacterial activities (Isnansetyo et al. 2003; Charyulu et al. 2009; Sharma and Kaur 2010). Therefore the bacterium P. putida NM-CH-I15-I was also tested for these properties by the diffusion methods against 5 representatives of the Gram-positive (Arthrobacter sp. AK-5, Bacillus subtilis PY79, Brevibacterium flavum CCM 251, Lysinibacillus sp. AK-11, Streptomyces coelicolor M145) and/or Gram-negative (Beta proteobacterium AK-23, E. coli, Ralstonia picketii MR-CH-I2 [MF102046], Stenotrophomonas chelatiphaga AK-32 [KJ510994], Bacteroidetes sp. AK-13 [KJ510975]) bacteria. The results showed that the bacterium

Table 4. Antibiotic resistance of the bacterium P. putida NM-CH-I15-I

\begin{tabular}{|c|c|c|c|c|c|c|c|c|c|c|}
\hline \multirow{2}{*}{ NM-CH-I15-I } & \multicolumn{10}{|c|}{ Antibiotic resistance } \\
\hline & Amp & $\mathrm{A} / \mathrm{C}$ & Cip & Ery & Gen & Cam & Pen & Rif & Tet & Van \\
\hline $\mathrm{IZ}(\mathrm{mm})$ & $\mathrm{R}(6)$ & $\mathrm{R}(9)$ & S (32) & $\mathrm{R}(6)$ & S (25) & $\mathrm{R}(6)$ & $\mathrm{R}(6)$ & $\mathrm{R}(8)$ & S (16) & $\mathrm{R}(6)$ \\
\hline
\end{tabular}

$\mathrm{IZ}$, inhibitive zone; R, resistance; I, intermediate resistance; $\mathrm{S}$, sensitive. Amp, ampicillin (10 $\mu \mathrm{g} /$ disc); A/C, amoxicillin/clavulanic acid (30 $\mu \mathrm{g} / \mathrm{disc}) ;$ Cip, ciprofloxacin $(5 \mu \mathrm{g} / \mathrm{disc}) ;$ Ery, erythromycin $(15 \mu \mathrm{g} / \mathrm{disc}) ; \mathrm{Gen}$, gentamycin $(120 \mu \mathrm{g} / \mathrm{disc})$; Cam, chloramphenicol (30 $\mu \mathrm{g} /$ disc); Pen, penicillin-G (10 $\mu \mathrm{g} /$ disc); Rif, rifampicin (5 $\mu \mathrm{g} / \mathrm{disc}) ;$ Tet, tetracycline (30 $\mu \mathrm{g} / \mathrm{disc})$; Van, vancomycin $(30 \mu \mathrm{g} / \mathrm{disc})$. The numbers in parenthesis indicate the inhibitive zones (in $\mathrm{mm}$ ). 
P. putida NM-CH-I15-I did not exhibit a noticeable inhibition aptitude against any of reference bacterial strains tested. The exception has posed only an intermediate inhibitory effect against Gram-positive bacterium Bacillus subtilis PY79 (Table 5). In addition, Remenár et al. (2015) have stated similar antibacterial activities among representatives of g-Proteobacteria isolated from same locality. Furthermore, many of $P$. putida strains are known as producers of different natural products including substances with antibacterial effects (Loeschcke and Thies 2015).

\section{Molecular identification of heavy-metal resistance determinant of the bacterium P. putida NM-CH-I15-I}

The identified bacterium P. putida NM-CH-I15-I [MG967453] has been found to carry nccA-like heavy-metal resistance determinant and its product was firstly marked as MR-CH-I15-HMR-I [KF218088]. On the base of phylogenetic analysis of its partial (581 bp) sequence it was tentatively assigned to $\mathrm{CzcA}$ protein from until now uncultured bacterial clone JH-S23-hmr [ADG65634] with 85\% similarity (Remenár et al. 2015). According to sequencing strategy of PCR amplicons covering a complete encoding area of $n c c$ A-like heavy-metal resistance gene and its neighbouring sequences partly before and partly after of its encoding area (in detail described in "Materials and Methods" section and Table S1) (Fig. 1), the whole nccA-like heavy-metal resistance gene sequence of 3,126 bp in length and of 1,042 amino acids (112,138 Da in molecular weight), respectively was obtained. The results from following phylogenetic analysis of complete nccA-like gene have confirmed its assignment to cation efflux system protein CzcA [SYX91347] from Pseudomonas reidholzensis with 93\% similarity (Fig. 3). Thus, this heavy-metal resistance gene sequence was marked as czcA-NM15I [MK704499]. P. reidholzensis CCOS $865^{\mathrm{T}}$ is a de novo identified species inside of $P$. putida group (99\% similarity to $P$. putida DSM 291T) and it has been isolated from forest soil in Switzerland in 2014 year (Frasson et al. 2017). The $c z c$ determinant encodes resistance against $\mathrm{Cd}^{2+}$, $\mathrm{Zn}^{2+}$ and $\mathrm{Co}^{2+}$ by metal-dependent efflux driven by the proton motive force of the CzcCBA complex (Nies 1995). This system is the best characterized by the CBA transporter from C. metallidurans $\mathrm{CH} 34$. Possession of this system makes a bacterium heavy metal resistant (Nies 2003). Really, the bacterium $P$. putida NM-CH-I15-I showed relatively high extent of resistance against nickel and copper, lower against zinc and markedly lower extent of resistance against cadmium and cobalt (Table 3 ).

\section{Expression of czcA-NM15I resistance gene}

RT-qPCR experiments were done to determine the effect of different concentrations of five heavy metals: $\mathrm{Ni}, 100 \mu \mathrm{g} / \mathrm{ml}$;
Table 5. Antibacterial effect of the bacterium P. putida NMCH-I15-I

\begin{tabular}{llc}
\hline Tested bacteria & IZ (mm) \\
\hline \multirow{5}{*}{ Gram-positive } & Arthrobacter sp. AK-5 & 6 \\
bacteria & Bacillus subtilis PY79 & 12 \\
& Lysinibacterium flavum CCM 251 & 6 \\
& Streptomyces coelicolor M145 & 8 \\
\hline \multirow{5}{*}{ Gram-negative } & Beta proteobacterium AK-23 & 7 \\
bacteria & Escherichia coli & 4 \\
& [MF102046] & 4 \\
& Stenotrophomonas chelatiphaga AK-32 & \\
& [KJ510994] & 4 \\
& Bacteroidetes sp. AK-13 [KJ510975] & 10 \\
\hline
\end{tabular}

$\mathrm{IZ} \leq 10 \mathrm{~mm}$, none inhibitory effect; $10 \mathrm{~mm}<\mathrm{IZ}<15 \mathrm{~mm}$, intermediate inhibitory effect; IZ $\geq 15 \mathrm{~mm}$, inhibitory effect. IZ, size of an inhibitive zone.

$\mathrm{Cd}, 25$ and $50 \mu \mathrm{g} / \mathrm{ml}$; Co, 10 and $50 \mu \mathrm{g} / \mathrm{ml} ; \mathrm{Zn}, 25$ and $50 \mu \mathrm{g} / \mathrm{ml}$; Cu, $50 \mu \mathrm{g} / \mathrm{ml}$ ) to changes level of expression of czcA-NM15I [MK704499]. RNA was isolated either from these five heavy metal-induced P. putida NM-CH-I15-I bacterial cells or from control sample (without heavy metal additions) in $45 \mathrm{~min}$ after $\mathrm{Ni}(100 \mu \mathrm{g} / \mathrm{ml}), \mathrm{Cd}$ and $\mathrm{Zn}$ $(25 \mu \mathrm{g} / \mathrm{ml})$, Co $(10 \mu \mathrm{g} / \mathrm{ml})$ and $\mathrm{Cu}(50 \mu \mathrm{g} / \mathrm{ml})$ additions or $1 \mathrm{~h}$ after $\mathrm{Cd}, \mathrm{Co}$ and $\mathrm{Zn}(50 \mu \mathrm{g} / \mathrm{ml})$ additions, respectively. The time points of RNA isolations and concentrations of individual heavy metals added were chosen according to responses of bacterial cells growth to inhibitory effects of individual heavy metals. These cells remained viable during such experiments. While Ni inhibited growth of bacterium up to the concentration of $100 \mu \mathrm{g} / \mathrm{ml} 45 \mathrm{~min}$ after $\mathrm{Ni}$ addition, at the same time $\mathrm{Cu}$ inhibited bacterial growth already at $50 \mu \mathrm{g} / \mathrm{ml}, \mathrm{Cd}$ and $\mathrm{Zn}$ at $25 \mu \mathrm{g} / \mathrm{ml}$ and Co even at $10 \mu \mathrm{g} / \mathrm{ml}$. Because the $c z c$ determinant encodes resistance against $\mathrm{Cd}^{2+}, \mathrm{Zn}^{2+}$ and $\mathrm{Co}^{2+}$ (Nies 1995), expression of this gene was examined also $1 \mathrm{~h}$ after $\mathrm{Cd}$, Co and $\mathrm{Zn}(50 \mu \mathrm{g} / \mathrm{ml})$ additions, respectively when the bacterial expressive growth was increased after $1 \mathrm{~h}$ of incubation. The expression gene pattern was normalised according to the reference gene $g d h \mathrm{~A}$. The results from RT-qPCR analysis showed that mainly zinc, cadmium and cobalt, and in lower extent also nickel has affected $c z c \mathrm{~A}-\mathrm{NM} 15 \mathrm{I}$ gene expression. On the other hand, copper did not significantly affect this gene expression (Fig. 4). czcA-NM15I gene expression increase up to 30-times by zinc influence (25 $\mu \mathrm{g} / \mathrm{ml}$ after $45 \mathrm{~min}$ induction), 26- and 18-times by cadmium influence, respectively $(50 \mu \mathrm{g} / \mathrm{ml}$ after $1 \mathrm{~h}$ and $25 \mu \mathrm{g} / \mathrm{ml}$ after $45 \mathrm{~min}$ induction, respectively) and 15-times by cobalt influence $(10 \mu \mathrm{g} / \mathrm{ml}$ after $45 \mathrm{~min}$ induction) are 


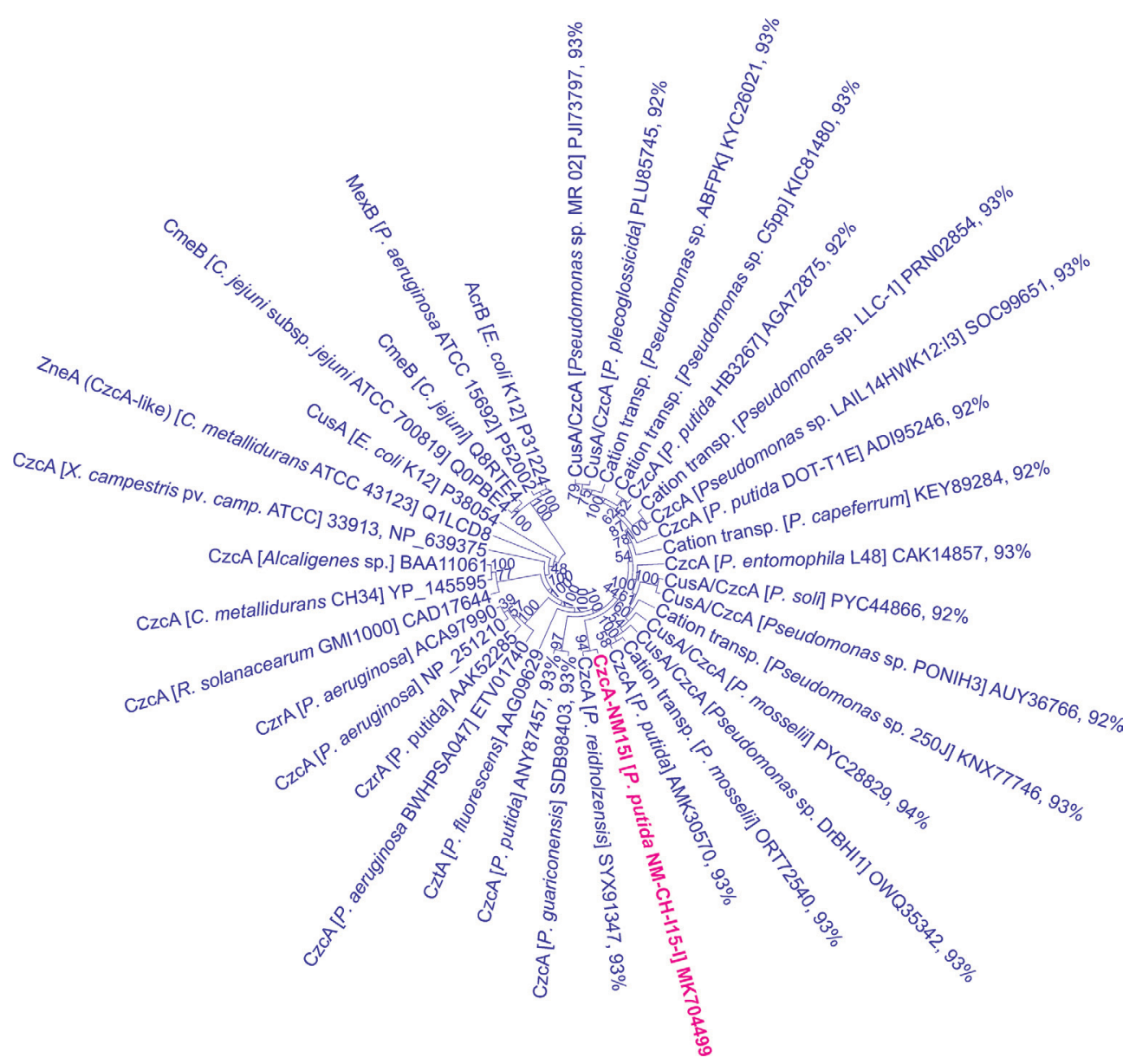

Figure 3. Unrooted phylogenetic tree obtained by the maximum likelihood method with 100 bootstrap replications showing phylogeny of whole CzcA-NM15I [MK704499] sequences based on 1,042 presented amino acid sites translated from DNA of the bacterium P. putida NM-CH-I15-I (in pink bold) and members of the genus Pseudomonas. Numbers in square brackets indicate the GenBank accession number and similarity to closest relative is shown after the clone designation. Sequences were aligned with ClustalW. (See online version for color figure).

not surprising according to the fact that the $c z c \mathrm{~A}-\mathrm{NM} 15 \mathrm{I}$ gene product has been identified as cation efflux system protein CzcA with 93\% similarity (Fig. 3) which mediates the induced resistance against cobalt, zinc and cadmium for bacterium C. metallidurans $\mathrm{CH} 34$ (Nies 2003) and for A. eutrophus (Nies et al. 1987; Nies 1992; Kunito et al. 1996) as well. These results suggested that the $c z c \mathrm{~A}-\mathrm{NM} 15 \mathrm{I}$ gene could preserve the resistance of bacterium $P$. putida NM-CH-I15-I against cobalt, zinc and cadmium. Interestingly, the higher $(50 \mu \mathrm{g} / \mathrm{ml})$ zinc and cobalt concentrations had almost any effect on $c z c \mathrm{~A}-\mathrm{NM} 15 \mathrm{I}$ gene expression (Fig. 4). Choudhary and Sar (2016) have presented similar results which found significant upregulation of $c z c \mathrm{~A}$ gene in $P$. aeruginosa strain upon exposure only to low concentrations of zinc and cadmium for short duration of their influences on bacterium. Similarly, Abdelatey et al.
(2011) have also confirmed the nccA-like gene inductions by addition of low cobalt and cadmium concentrations to the medium in Pseudomonas sp. and Bordetella sp. strains isolated from heavy-metal contaminated soils. This fact could be related to heavy-metal concentrations in environment from which were bacteria isolated and it appears that expression of resistance determinants is adapted to bacterial requirements in given environments.

However, the gene expression level increase up to 12 -times by $100 \mu \mathrm{g} / \mathrm{ml}$ nickel influence after $45 \mathrm{~min}$ induction was also observed but after copper addition (50 $\mu \mathrm{g} / \mathrm{ml}$ after $45 \mathrm{~min}$ induction), approximately only up to 3-times $c z c \mathrm{~A}$-NM15I gene expression increase was observed (Fig. 4). While the low czcA-NM15I gene expression by copper influence was possible, the significant $\mathrm{Ni}$-induction of this gene is surprising because the func- 
tion of the combined nickel-cobalt-cadmium resistance is mediated by the CzcCB2A-related NccCBA efflux system from A. xylosoxidans (Schmidt and Schlegel 1994). But, in some occasions, $\mathrm{Ni}^{2+}$ and $\mathrm{Co}^{2+}$ are exported by the same CBA transporters as $\mathrm{Zn}^{2+}$ and $\mathrm{Cd}^{2+}$ (for example NccCBA from Alcaligenes xylosoxidans $31 \mathrm{~A}$ and CzcCBA from C. metallidurans CH34) (Schmidt and Schlegel 1994; Legatzki et al. 2003). This suggestion could be related first of all to fact that the natural environment of bacterial strain P. putida NM-CH-I15-I was contaminated mainly by high nickel concentrations.

These results suggested that bacterial strain P. putida NM$\mathrm{CH}-\mathrm{I} 15-\mathrm{I}$ carry $c z c \mathrm{~A}-\mathrm{NM} 15 \mathrm{I}$ resistance gene mainly against cobalt, zinc and cadmium, and in lower extent probably also against nickel. On the other hand, the observed relatively high extent of resistance of bacterium P. putida NM-CH-I15I against nickel and copper, lower against zinc and markedly lower extent of resistance against cadmium and cobalt (Table 3) suggested that the resistance of this bacterium is besides of $c z c \mathrm{~A}-\mathrm{NM} 15 \mathrm{I}$ resistance gene probably mediated by different mechanisms as well.

\section{Detection of CzcA-NM15I protein in E. coli BL21 (DE3) cells}

The $c z c \mathrm{~A}-\mathrm{NM} 15 \mathrm{I}$ gene product was heterologous expressed from synthetic variant of $c z c \mathrm{~A}-\mathrm{NM} 15 \mathrm{I}$ gene cloned into pET-21a(+) plasmid (General Biosystems, Inc., USA) in E. coli BL21 (DE3) cells induced by 1 mM IPTG (final concentration). The protein extraction was realised by culture sonication under non-denaturing (without urea addition) as well as denaturing (with urea addition) conditions and protein extracts obtained were subsequently purified by use of Ni-columns HisTrap HP (GE Healthcare UK Limited, UK). Protein extracts were finally analysed by use of SDS-PAGE and CzcA-NM15I protein was detected by use of Western immunoblot methods. SDS-PAGE analysis showed that while in protein extract obtained under denaturing conditions were found some of distinguishable bands including those in area with supposed molecular weight of CzcA-NM15I protein of about $112,138 \mathrm{Da}$, in protein extract obtained under nondenaturing conditions was visible none of protein bands in this area. However, visible CzcA-NM15I protein bands in the area of about $112,138 \mathrm{Da}$ did not demonstrate significant increased protein expressions (Fig. 5A). Therefore to detect a desired CzcA-NM15I protein band of about 112,138 Da, the Western immunoblot semi-dry methods was used with monoclonal anti His tag antibody (PentaxHis Antibody, Qiagen, Germany) as primary and antimouse IgG-AP (Sigma-Aldrich, USA) as secondary antibodies, respectively. The results from immunoblot analysis showed that protein extract samples prepared under denaturing conditions was on the membrane detected a coloured band which indicated
CzcA-NM15I protein with supposed molecular weight of about $112,138 \mathrm{Da}$. On the other hand, the CzcA-NM15I protein was not detected in any single one sample from protein extracts prepared under non-denaturing conditions (Fig. 5B).

Although the bands indicating CzcA-NM15I protein were detected in protein extract samples prepared under denaturing conditions, the coloured reaction was relatively low. The low degree of this protein induction could be related partly to complicate induction of transmembrane proteins but also with use of urea as denaturised reagent instead of some detergents. CzcA-NM15I protein is transmembrane and bogged down into cell membrane structures so that the production, isolation and purification of these protein types are complicated. The transmembrane protein extractions require the use of suitable detergent for phospholipid bilayer disruptions owing to hydrophobic nature of transmembrane segments inside of membrane protein structures (Smith 2011).

\section{The molecular modelling of CzcA-NM15I protein from bacterium P. putida NM-CH-I15-I}

ZneA from Cupriavidus metallidurans $\mathrm{CH} 34$ (Pak et al. 2013) and CusA from E. coli (Franke et al. 2003; Su et al. 2012) proteins were found as the evolutionary relatives to the CzcA-NM15I protein from P. putida NM-CH-I15-I and which participate in resistance against heavy metals and are well characterised on molecular base. Both these proteins represent the efflux pumps. While ZneA is the efflux pump specific for $\mathrm{Zn}^{2+}$ cation efflux, CusA for $\mathrm{Cu}^{+}$and $\mathrm{Ag}^{+}$. Inside of $Z$ neA protein structure, two amino acids were found which are participated on $\mathrm{Zn}^{2+}$ cation transports, aspartate located in positions 393 and 399, (D393 and D399, respec-

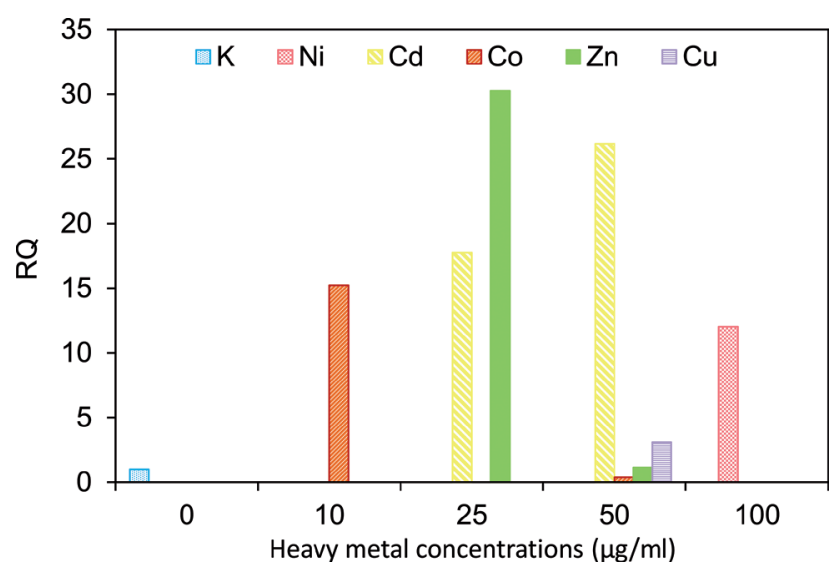

Figure 4. Change of $c z c \mathrm{~A}-\mathrm{NM} 15 \mathrm{I}$ [MK704499] gene expression after heavy metal additions to the medium analysed by use of Realtime PCR (RT-qPCR). $R Q=2^{-\Delta \Delta C q}$, where $\Delta \Delta C q=$ the differences of fluorescence level changes of induced and control sample. 
A

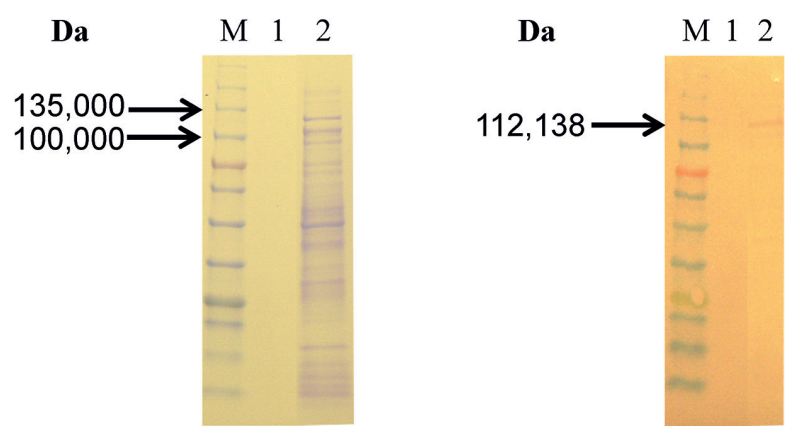

Figure 5. The heterologous expression of synthetic variant of $c z c$ A-NM15I gene cloned into pET-21a(+) plasmid (General Biosystems, Inc., USA) in E. coli BL21 (DE3) cells induced by $1 \mathrm{mM}$ IPTG. In detail, 4-20\% polyacrylamide gel electrophoresis of protein extracts purified by Ni-columns HisTrap HP (GE Healthcare UK Limited, UK) and stained by Coomassie brilliant blue R-250 (A) and Western immunoblot assay with monoclonal anti His tag antibody (PentaxHis Antibody, Qiagen, Germany) as primary and antimouse IgG-AP (Sigma-Aldrich, USA) as secondarily antibodies, respectively (B). Lanes: $\mathrm{M}$, protein marker VI (10-245); 1, protein extracts obtained under non-denaturing (without urea addition) conditions; 2, protein extracts obtained under denaturing (with urea addition) conditions.

tively) and glutamate located in position 406 (E406) (Pak et al. 2013). In addition, inside of CusA protein structure, four amino acids were found which are participated on $\mathrm{Cu}^{+}$transport, arginine located in positions 83 and 669 (R83, R669. respectively), glutamate in positions 567 and 625 (E567, E625, respectively), aspartate in position 617 (D617) and lysine in position 678 (K678) (Su et al. 2012). Furthermore, inside of CusA protein structure, also methionine was found located in three positions, 573, 623 and 672 (M573, M623 and M672, respectively) in which it plays a major role at the resistance assignment of the bacterium E. coli against copper (Franke et al. 2003).

The sequences of these two proteins (https://www.uniprot. org/) together with CzcA-NM15I protein sequence were used for the construction of alignment (Fig. S2). Alignment of protein sequences ZneA from C. metallidurans $\mathrm{CH} 34$ and CzcA-NM15I from P. putida NM-CH-I15-I showed that the positions of aspartate (D393, D399) and glutamate (E406), amino acids which participate on $\mathrm{Zn}^{2+}$ cation transports in ZneA protein (Pak et al. 2013) corresponded with same amino acids in positions D402, D408 and E415 in the czcA-NM15I protein sequence (Fig. S2).

In addition, the comparison of the amino acid positions R83, E567, D617, E625, R669 and K678 in CusA protein sequence from $E$. coli with same amino acid positions in CzcA-NM15I protein sequence from P. putida NM-CH-I15-I showed that while arginine in positions 83 and 669 (R83 and R669, respectively), glutamate in position 567 (E567) and aspartate in position 617 (D617) in CusA protein from $E$. coli corresponded with these amino acids in positions R83 and R673, E568 and D619 in CzcA-NM15I protein, two remaining amino acids, glutamate in position 625 (E625) and lysine in position 678 (K678) in CusA protein from E. coli were not corresponded with these amino acids in appropriate positions, 627 and 682, respectively in CzcA-NM15I protein. In this protein, aspartate in position 627 (D627) was occurred instead of glutamate, and in position 682, an arginine (R682) instead of lysine was occurred (Fig. S2).

Furthermore, in CusA protein, methionine (M573, M623, M672) plays an important role at the resistance assignment of the bacterium E. coli against copper as well (Franke et al. 2003). However, in CzcA-NM15I protein, instead of methionine other amino acids were localised in appropriate positions 574, 625 and 676 as follow: glutamine (Q574), isoleucine (I625) and glutamate (E676), respectively (Fig. S2).

Moreover, aspartate (D602) in ZneA protein from C. metallidurans $\mathrm{CH} 34$ was found as an absolutely conserved in CzcA protein in position 619 (D619) as well as in CusA protein from E. coli in position 617 (D617) (Pak et al. 2013). This amino acid was localised in CzcA-NM15I protein from P. putida NM-CH-I15-I in same position (D619) as in CzcA (Fig. S2). In CusA, the mutation in D617 caused reduction of $\mathrm{Cu}^{+}$transport activity (Su et al. 2012), despite the observation that $\mathrm{D} 617$ was adjacent to the $\mathrm{Cu}^{+}$binding site and forms no interactions with $\mathrm{Cu}^{+}$(Long et al. 2010). In ZneA, the mutation in D602 resulted in affinity reduction for $\mathrm{Zn}^{2+}$ (Pak et al. 2013). These results suggested that in CzcANM15I protein from P. putida NM-CH-I15-I, aspartate in position 619 (D619) could be participate on zinc transport, possibly cobalt and cadmium as well. Similarly, in ZneA, localisation and direction of the carboxylate side chains on two amino acids, aspartate (D393, D399) and glutamate (E406) suggested theirs possible role in proton translocation. Indeed, mutagenesis of the corresponding conserved residues in CzcA (D402N, D408N, or E415Q) all lead to the loss of proton-dependent transport activity for $\mathrm{Co}^{2+}, \mathrm{Zn}^{2+}$, and $\mathrm{Cd}^{2+}$ (Goldberg et al. 1999). This assumption supports also finding that polar residues in the transmembrane domain of RND efflux pumps have been shown to be critical for transport, and have been suggested to be the sites of proton translocation (Goldberg et al. 1999; Murakami and Yamaguchi 2003; Takatsuka and Nikaido 2006; Seeger et al. 2009). There is an interesting finding in this context that in same positions as in CzcA protein, acidic residues of these two amino acids (D402, D408, E415) were found also in CzcA-NM15I protein from P. putida NM-CH-I15-I (Fig. S2).

Finally, the homology model of CzcA-NM15I protein was constructed using Phyre ${ }^{2}$ programme (Kelley et al. 


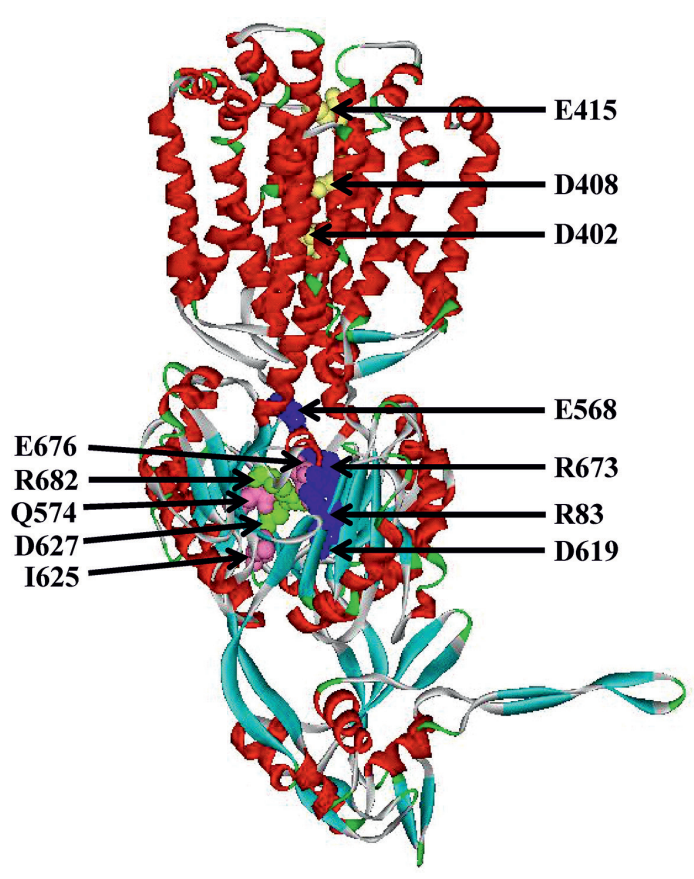

Figure 6. The homology model of CzcA-NM15I protein from P. putida NM-CH-I15-I was constructed on the base of ZneA protein known structure from $C$. metallidurans $\mathrm{CH} 34$ by use of Phyre $^{2}$ programme (Kelley et al. 2015). Red colour, a-helixes; turquoise colour, b-filaments; yellow colour, functionally important amino acids and their positions in homology model of CzcANM15I protein from P. putida NM-CH-I15-I which correspond with amino acids in appropriate positions in ZneA protein from C. metallidurans $\mathrm{CH} 34$ participating in metal cation transports; blue colour, amino acids and their positions in homology model of CzcA-NM15I protein which correspond with amino acids in appropriate positions in CusA protein from E. coli participating in copper transport; green and pink colour, amino acids and their positions in homology model of CzcA-NM15I protein which not correspond with amino acids in appropriate positions in CusA protein from E. coli participating in copper transport. (See online version for color figure).

2015) on the template of ZneA protein from C. metallidurans $\mathrm{CH} 34$ registered under number $4 \mathrm{~K} 0 \mathrm{E}$ in Protein data bank which is composed mainly from a-helixes and b-strands (Fig. 6). The functions of both proteins are similar, while ZneA protein as an efflux pump specific for $\mathrm{Zn}^{2+}$ cation effluxes is participated on bacterium C. metallidurans CH34 resistance against zinc (Pak et al. 2013), CzcA-NM15I protein as an efflux pump is participated besides on resistance against zinc also on resistance against cobalt and cadmium of bacterium $P$. putida NM-CH-I15-I. On the base of CzcA-NM15I protein homology model it was able to localise such amino acids which were identified on the base of CzcA-NM15I protein sequence alignment with protein sequences of ZneA from C. metallidurans
CH34 and CusA from E. coli (Fig. S2) and which could potentially participate in metal cation transport in CzcANM15I protein. The amino acid localisations, such as arginine in positions 83 and 673 (R83, R673), aspartate in positions 402, 408 and 619 (D402, D408, D619) and glutamate in positions 415 and 568 (E415, E568) in the homology model of CzcA-NM15I protein suggested that these amino acids can play very important role at the transport of one or more cations such as cobalt, zinc or cadmium (Fig. S2 and Fig. 6).

The presented results suggested that bacterium $P$. putida NM-CH-I15-I [MG967453] previously isolated from heavymetal contaminated soil, mainly by high nickel concentration and carrying CzcA-NM15I [MK704499] resistance gene mainly against cobalt, zinc and cadmium and to a lesser extent against nickel as well, could be a new type strain of bacterium P. putida.

Acknowledgements. This work was supported by VEGA Grant No. 2/0019/17 from Slovak grant agency. We thank Dr. Š. Janeček for his helpful advice on the molecular modelling approaches.

\section{References}

Abdelatey LM, Khalil WKB, Alit TH, Mahrous KF (2011): Heavy metal resistance and gene expression analysis of metal resistance genes in Gram-positive and Gram-negative bacteria present in Egyptian soils. J. Appl. Sci. Environ. Sanit. 6, 201-211

Bogdanova ES, Bass IA, Minakhin LS, Petrova MA, Mindlin SZ, Volodin AA, Kalyaeva ES, Tiedje JM, Hobman JL, Brown NL, Nikiforov VG (1998): Horizontal spread of mer operons among Gram-positive bacteria in natural environments. Microbiology 144, 609-620 https://doi.org/10.1099/00221287-144-3-609

Bohuš P, Klinda J (2010): Environmental Regionalization in Slovak Republic. Bratislava: MŽP SR, Banská Bystrica: SAŽP, pp. 9-21 (in Slovak)

Bustin SA, Benes V, Garson JA, Hellemans J, Huggett J, Kubista M, Mueller R, Nolan T, Pfaffl MW, Shipley GL, Vandesompele J, Wittwer CT (2009): The MIQE guidelines: minimum information for publication of quantitative real-time PCR experiments. Clin. Chem. 55, 611-622 https://doi.org/10.1373/clinchem.2008.112797

Case RJ, Boucher Y, Dahllöf I, Holmström C, Doolittle WF, Kjelleberg S (2007): Use of $16 \mathrm{~S}$ rRNA and rpoB genes as molecular markers for microbial ecology studies. Appl. Environ. Microbiol. 73, 278-288 https://doi.org/10.1128/AEM.01177-06

Charyulu EM, Sekaran G, Rajakumar GS, Gnanamani A (2009): Antimicrobial activity of secondary metabolite from marine isolate, Pseudomonas sp. against Gram positive and negative bacteria including MRSA. Indian J. Exp. Biol. 47, 964-968

Choudhary S, Sar P (2016): Real-time PCR based analysis of metal resistance genes in metal resistant Pseudomonas aeruginosa strain J007. J. Basic Microbiol. 56, 688-697 https://doi.org/10.1002/jobm.201500364 
Chovanová K, Sládeková D, Kmet’ V, Prokšová M, Harichová J, Puškárová A, Polek B, Ferianc P (2004): Identification and characterization of eight cadmium resistant bacterial isolates from a cadmium-contaminated sewage sludge. Biologia (Bratislava) 59, 817-827

Erbe JL, Taylor KB, Hall LM (1995): Metalloregulation of the cyanobacterial smt locus: identification of $\mathrm{SmtB}$ binding sites and direct interaction with metals. Nucleic Acids Res. 23, 2472-2478 https://doi.org/10.1093/nar/23.13.2472

Franke S, Grass G, Rensing C, Nies DH (2003): Molecular analysis of the copper-transporting efflux system CusCFBA of Escherichia coli. J. Bacteriol. 185, 3804-3812 https://doi.org/10.1128/JB.185.13.3804-3812.2003

Frasson D, Picozzi T, Torossi T, Balada S, Smits THM, Hilber U (2017): Pseudomonas wadenswilerensis sp. nov. and Pseudomonas reidholzensis sp. nov., two novel species within the Pseudomonas putida group isolated from forest soil. Int. J. Syst. Evol. Microbiol. 67, 2853-2861 https://doi.org/10.1099/ijsem.0.002035

Goldberg M, Pribyl T, Juhnke S, Nies DH (1999): Energetics and topology of $\mathrm{CzcA}$, a cation/proton antiporter of the resistancenodulation-cell division protein family. J. Biol. Chem. 274, 26065-26070 https://doi.org/10.1074/jbc.274.37.26065

Greening C, Carere C, Rushton-Green R, Harold LK, Hards K, Taylor MC, Morales SE, Stott MB, Cook GM (2015): Persistence of the dominant soil phylum Acidobacteria by trace gas scavenging. Proc. Natl. Acad. Sci. USA 112, 10497-10502

https://doi.org/10.1073/pnas.1508385112

Hassen A, Saidi N, Cherif M, Boudabous A (1998): Resistance of environmental bacteria to heavy metals. Bioresourc. Technol. 64, 7-15 https://doi.org/10.1016/S0960-8524(97)00161-2

Harichová J, Karelová E, Pangallo D, Ferianc P (2012): Structure analysis of bacterial community and their heavy-metal resistance determinants in the heavy-metal-contaminated soil sample. Biologia (Bratislava) 67, 1038-1048 https://doi.org/10.2478/s11756-012-0123-9

He Z, Piceno Y, Deng Y, Xu M, Lu Z, Desantis T, Andersen G, Hobbie SE, Reich PB, Zhou J (2012): The phylogenetic composition and structure of soil microbial communities shifts in response to elevated carbon dioxide. ISME J. 6, 259-272 https://doi.org/10.1038/ismej.2011.99

Hilario E, Buckley T, Young J (2004): Improved resolution on the phylogenetic relationships among Pseudomonas by the combined analysis of atpD, carA, recA and $16 \mathrm{~S}$ rDNA. Antonie van Leeuwenhoek 86, 51-64 https://doi.org/10.1023/B:ANTO.0000024910.57117.16

$\mathrm{Hu}$ N, Zhao B (2007): Key genes involved in heavy-metal resistance in Pseudomonas putida CD2. FEMS Microbiol. Lett. 267, 17-22 https://doi.org/10.1111/j.1574-6968.2006.00505.x

Hussain MB, Ali S, Azam A, Hina S, Farooq MA, Ali B, Azam A, Bharwana SA, Gill MB (2013): Morphological, physiological and biochemical responses of plants to nickel stress: a review. Afr. J. Agr. Res. 8, 1596-1602 https://doi.org/10.5897/AJAR12.407

Isnansetyo A, Cui L, Hiramatsu K, Kamei Y (2003): Antibacterial activity of 2,4-diacetylphloroglucinol produced by
Pseudomonas sp. AMSN isolated from a marine alga, against vancomycin-resistant Staphylococcus aureus. Int. J. Antimicrob. Agents 22, 545-547

https://doi.org/10.1016/S0924-8579(03)00155-9

Ji G, Silver S (1992): Regulation and expression of the arsenic resistance operon from Staphylococcus aureus plasmid pI258. J. Bacteriol. 174, 3684-3694

https://doi.org/10.1128/JB.174.11.3684-3694.1992

Johnson JM, Church GM (1999): Alignment and structure prediction of divergent protein families: periplasmic and outer membrane proteins of bacterial efflux pumps. J. Mol. Biol. 287, 695-715 https://doi.org/10.1006/jmbi.1999.2630

Kaeberlein T, Lewis K, Epstein SS (2002): Isolating ,uncultivable“ microorganisms in pure culture in a simulated natural environment. Science 296, 1127-1129

https://doi.org/10.1126/science.1070633

Karelová E, Harichová J, Stojnev T, Pangallo D, Ferianc P (2011): The isolation of heavy-metal resistant culturable bacteria and resistance determinants from a heavy-metal-contaminated site. Biologia (Bratislava) 66, 18-26 https://doi.org/10.2478/s11756-010-0145-0

Kelley LA, Mezulis S, Yates CM, Wass MN, Sternberg MJ (2015): The Phyre2 web portal for protein modeling, prediction and analysis. Nat. Protoc. 10, 845-858

https://doi.org/10.1038/nprot.2015.053

Kunito T, Kusano T, Oyaizu H, Senoo K, Kanazawa S, Matsumoto S (1996): Cloning and sequence analysis of czc genes in Alcaligenes sp. strain CT14. Biosci. Biotechnol. Biochem. 60, 699-704 https://doi.org/10.1271/bbb.60.699

Laemmli UK (1970): Cleavage of structural proteins during the assembly of the head of the bacteriophage T4. Nature 227, 680-685 https://doi.org/10.1038/227680a0

Lane DJ (1991): 16S/23S rRNA sequencing. In: Nucleic Acid Techniques in Bacterial Systematics (Eds. E Stackebrandt and M Goodfellow), pp. 115-148, John Wiley \& Sons, New York

Lang JM, Darling AE, Eisen JA (2013): Phylogeny of bacterial and archaeal genomes using conserved genes: Supertrees and Supermatrices. PLoS One 8, e62510 https://doi.org/10.1371/journal.pone.0062510

Legatzki A, Franke S, Lucke S, Hofmann TA, Neumann D, Nies DH (2003): First step towards a quantitative model describing Czcmediated heavy metal resistance in Ralstonia metallidurans. Biodegradation 14, 153-168 https://doi.org/10.1023/A:1024043306888

Lima SAA, Carvalho MA, Souza SA, Dias PM, Silva FRG, Meirelles SCS, Melo BCA, Hofer E (2012): Heavy metal tolerance (Cr, Ag and $\mathrm{Hg}$ ) in bacteria isolated from sewage. Braz. J. Microbiol. 43, 1620-1631 https://doi.org/10.1590/S1517-83822012000400047

Liu W, Li L, Khan MA, Zhu F (2012): Popular molecular markers in bacteria. Mol. Gen. Mikrobiol. Virusol. 3, 14-17 https://doi.org/10.3103/S0891416812030056

Livak KJ, Schmittgen TD (2001): Analysis of relative gene expression data using real-time quantitative PCR and the 2(-Delta Delta C(T)) method. Methods 25, 402-408 https://doi.org/10.1006/meth.2001.1262 
Loeschcke A, Thies S (2015): Pseudomonas putida - a versatile host for the production of natural products. Appl Microbiol Biotechnol. 99, 6197-6214 https://doi.org/10.1007/s00253-015-6745-4

Long F, Su CC, Zimmermann MT, Boyken SE, Rajashankar KR, Jernigan RL, Yu EW (2010): Crystal structures of the CusA efflux pump suggest methionine-mediated metal transport. Nature 467, 484-488 https://doi.org/10.1038/nature09395

Maddison W (1997): Gene trees in species trees. Systematic Biology $46,523-536$ https://doi.org/10.1093/sysbio/46.3.523

Mao Z, Li M, Chen J (2013): Draft genome sequence of Pseudomonas plecoglossicida strain NB2011, the causative agent of white nodules in large yellow croaker (Larimichthys crocea). Genome Announc 1, e00586-13 https://doi.org/10.1128/genomeA.00586-13

Mcintosh D, Cunningham M, Ji B, Fekete FA, Parry EM, Clark SE, Zalinger ZB, Gilg IC, Danner GR, Johnson KA, Beattie M, Ritchie R (2008): Transferable, multiple antibiotic and mercury resistance in Atlantic Canadian isolates of Aeromonas salmonicida subsp. salmonicida is associated with carriage of an IncA/C plasmid similar to the Salmonella enterica plasmid pSN254. J. Antimicrob. Chemother. 61, 1221-1228 https://doi.org/10.1093/jac/dkn123

Meireles C, Costa G, Guinote I, Albuquerque T, Botelho A, Cordeiro C, Freire P (2013): Pseudomonas putida are environmental reservoirs of antimicrobial resistance to $\beta$-lactamic antibiotics. World J. Microbiol. Biotechnol. 29, 1317-1325 https://doi.org/10.1007/s11274-013-1295-3

Mekki A, Sayadi S (2017): Study of heavy metal accumulation and residual toxicity in soil saturated with phosphate processing wastewater. Water Air Soil Pollut. 228, 215 https://doi.org/10.1007/s11270-017-3399-0

Mergeay M, Monchy S, Vallaeys T, Auquier V, Benotmane A, Bertin P, Taghavi S, Dunn J, Van der Lelie D, Wattiez R (2003) Ralstonia metallidurans, a bacterium specifically adapted to toxic metals: towards a catalogue of metal-responsive genes. FEMS Microbiol. Rev. 27, 385-410 https://doi.org/10.1016/S0168-6445(03)00045-7

Mobley HL, Chen CM, Silver S, Rosen BP (1983): Cloning and expression of R-factor mediated arsenate resistance in Escherichia coli. Mol. Gen. Genet. 191, 421-426 https://doi.org/10.1007/BF00425757

Muñoz AJ, Ruiz E, Abriouel H, Gálvez A, Ezzouhri L, Espínola F (2012): Heavy metal tolerance of microorganisms isolated from wastewaters: Identification and evaluation of its potential for biosorption. Chem. Engin. J. 210, 325-332 https://doi.org/10.1016/j.cej.2012.09.007

Murakami S, Yamaguchi A (2003): Multidrug-exporting secondary transporters. Curr. Opin. Struct. Biol. 13, 443-452 https://doi.org/10.1016/S0959-440X(03)00109-X

Nakazawa T (2002): Travels of a Pseudomonas, from Japan around the world. Environ Microbiol. 4, 782-786 https://doi.org/10.1046/j.1462-2920.2002.00310.x

Nascimento AMA, Chartone-Souza E (2003): Operon mer: bacterial resistance to mercury and potential for bioremediation of contaminated environments. Genet. Mol. Res. 2, 92-101
Nelson KE, Weinel C, Paulsen IT, Dodson RJ, Hilbert H, Martins Dos Santos VA, Fouts DE, Gill SR, Pop M, Holmes M, et al. (2002): Complete genome sequence and comparative analysis of the metabolically versatile Pseudomonas putida KT2440. Environ Microbiol. 4, 799-808 https://doi.org/10.1046/j.1462-2920.2002.00366.x

Nies D, Mergeay M, Friedrich B, Schlegel HG (1987): Cloning of plasmid genes encoding resistance to cadmium, zinc, and cobalt in Alcaligenes eutrophus CH34. J. Bacteriol. 169, $4865-4868$ https://doi.org/10.1128/JB.169.10.4865-4868.1987

Nies DH (1992): CzcR and CzcD, gene products affecting regulation of resistance to cobalt, zinc and cadmium (czc system) in Alcaligenes eutrophus. J. Bacteriol. 174, 8102-8110 https://doi.org/10.1128/JB.174.24.8102-8110.1992

Nies DH (1995): The cobalt, zinc, and cadmium efflux system Cz$\mathrm{cABC}$ from Alcaligenes eutrophus functions as a cation-protonantiporter in Escherichia coli. J. Bacteriol. 177, 2707-2712 https://doi.org/10.1128/JB.177.10.2707-2712.1995

Nies DH (1999): Microbial heavy metal resistance. Appl. Microbiol. Biotechnol. 51, 730-750. https://doi.org/10.1007/s002530051457

Nies DH (2003): Efflux-mediated heavy metal resistance in prokaryotes. FEMS Microbiol. Rev. 27, 313-339 https://doi.org/10.1016/S0168-6445(03)00048-2

Özen AI, Ussery DW (2012): Defining the Pseudomonas Genus: Where do we draw the line with Azotobacter? Microb. Ecol. 63, 239-248 https://doi.org/10.1007/s00248-011-9914-8

Pak JE, Ekendé EN, Kiflea EG, O‘Connell III JD, De Angelis F, Tessema MB, Derfoufi KM, Robles-Colmenares Y, Robbins RA, Goormaghtigh E, et al. (2013): Structures of intermediate transport states of $\mathrm{ZneA}$, a $\mathrm{Zn}(\mathrm{II}) /$ proton antiporter. PNAS 110, 18484-18489 https://doi.org/10.1073/pnas.1318705110

Panagos P, Van Liedekerke M, Yigini Y, Montanarella L (2013): Contaminated sites in Europe: Review of the current situation based on data collected through an European network. J. Environ. Public Health 2013, 158764 https://doi.org/10.1155/2013/158764

Paulsen IT, Park JH, Choi PS, Saier MHJ (1997): A family of Gramnegative bacterial outer membrane factors that function in the export of proteins, carbohydrates, drugs and heavy metals from Gram-negative bacteria. FEMS Microbiol. Lett. 156, 1-8 https://doi.org/10.1016/S0378-1097(97)00379-0

Peña A, Busquets A, Gomila M, Mulet M, Gomila RM, Reddy TBK, Huntemann M, Pati A, Ivanova N, Markowitz V, et al. (2016): High quality draft genome sequences of Pseudomonas fulva DSM 17717T, Pseudomonas parafulva DSM 17004T and Pseudomonas cremoricolorata DSM 17059T type strains. Stand Genomic Sci. 11, 55 https://doi.org/10.1186/s40793-016-0178-2

Ramette A, Tiedje JM (2007): Biogeography: an emerging cornerstone for understanding prokaryotic diversity, ecology, and evolution. Microb. Ecol. 53, 197-207

https://doi.org/10.1007/s00248-005-5010-2

Remenár M, Karelová E, Harichová J, Zámocký M, Kamlárová A, Ferianc P (2015): Isolation of previously uncultivable 
bacteria from a nickel contaminated soil using a diffusionchamberbased approach. Appl. Soil Ecol. 95, 115-127 https://doi.org/10.1016/j.apsoil.2015.06.013

Rosenstein R, Peschel A, Wieland B, Götz F (1992): Expression and regulation of the antimonite, arsenite, and arsenate resistance operon of Staphylococcus xylosus plasmid pSX267. J. Bacteriol. 174, 3676-3683 https://doi.org/10.1128/JB.174.11.3676-3683.1992

Saier MHJ, Tam R, Reizer A, Reizer J (1994): Two novel families of bacterial membrane proteins concerned with nodulation, cell division and transport. Mol. Microbiol. 11, 841-847 https://doi.org/10.1111/j.1365-2958.1994.tb00362.x

Saltikov CW, Olson BH (2002): Homology of Escherichia coli $\mathrm{R} 773$ ars $\mathrm{A}$, arsB, and ars $\mathrm{C}$ genes in arsenic-resistant bacteria isolated from raw sewage and arsenic-enriched creek waters. Appl. Environ. Microbiol. 68, 280-288 https://doi.org/10.1128/AEM.68.1.280-288.2002

Salvador M, Carolina G, Jose E (2007): Novel nickel resistance genes from the rhizosphere metagenome of plants adapted to acid mine drainage. Appl. Environ. Microbiol. 73, 6001-6011 https://doi.org/10.1128/AEM.00048-07

Schmidt T, Schlegel HG (1994): Combined nickel-cobaltcadmium resistance encoded by the ncc locus of Alcaligenes xylosoxidans 31A. J. Bacteriol. 176, 7045-7054 https://doi.org/10.1128/JB.176.22.7045-7054.1994

Seeger MA, Ballmoos C, Verrey F, Pos KM (2009): Crucial role of Asp408 in the proton translocation pathway of multidrug transporter AcrB: Evidence from site-directed mutagenesis and carbodiimide labeling. Biochemistry 48, 5801-5812 https://doi.org/10.1021/bi900446j

Sharma S, Kaur M (2010): Antimicrobial activities of rhizobacterial strains of Pseudomonas and Bacillus strains isolated from rhizosphere soil of carnation (Dianthus caryophyllus cv. Sunrise). Indian J. Microbiol. 50, 229-232

https://doi.org/10.1007/s12088-010-0045-6

Silver S, Phung LT (1996): Bacterial heavy metal resistance: New surprises. Ann. Rev. Microbiol. 50, 753-789 https://doi.org/10.1146/annurev.micro.50.1.753

Smith SM (2011): Strategies for the purification of membrane proteins. Methods. Mol. Biol. 681, 485-496 https://doi.org/10.1007/978-1-60761-913-0_29

Stanier RY, Palleroni NJ, Doudoroff M (1966): The aerobic pseudomonads: a taxonomic study. J. Gen. Microbiol. 43, 159-271 https://doi.org/10.1099/00221287-43-2-159

Su CC, Long F, Lei HT, Bolla JR, Do SV, Rajashankar KR, Yu EW (2012): Charged amino acids (R83, E567, D617, E625, R669, and K678) of CusA are required for metal ion transport in the Cus ffflux system. J. Mol. Biol. 422, 429-441 https://doi.org/10.1016/j.jmb.2012.05.038

Sydow M, Chrzanowski L, Cedergreen N, Owsianiak M (2017): Limitations of experiments performed in artificially made OECD standard soils for predicting cadmium, lead and zinc toxicity towards organisms living in natural soils. J. Environ. Manage. 198, $32-40$ https://doi.org/10.1016/j.jenvman.2017.04.092
Takatsuka Y, Nikaido H (2006): Threonine-978 in the transmembrane segment of the multidrug efflux pump AcrB of Escherichia coli is crucial for drug transport as a probable component of the proton relay network. J. Bacteriol. 188, 7284-7289 https://doi.org/10.1128/JB.00683-06

Tamura K, Peterson D, Peterson N, Stecher G, Nie M, Kumar S (2011): „MEGA5: Molecular evolutionary genetics analysis using maximum likelihood, evolutionary distance, and maximum parsimony methods“. Mol. Biol. Evol. 28, 2731-2739 https://doi.org/10.1093/molbev/msr121

Torsvik V, Ovreas L (2002): Microbial diversity and function in soil: from gene to ecosystems. Curr. Opin. Microbiol. 5, 240-245 https://doi.org/10.1016/S1369-5274(02)00324-7

Tseng T-T, Gratwick KS, Kollman J, Park D, Nies DH, Goffeau A, Saier MHJ (1999): The RND superfamily: an ancient, ubiquitous and diverse family that includes human disease and development proteins. J. Mol. Microbiol. Biotechnol. 1, 107-125

Vinje H, Almøy T, Liland KH, Snipen L (2014): A systematic search for discriminating sites in the $16 \mathrm{~S}$ ribosomal RNA gene. Microb Inform Exp. 4, 2 https://doi.org/10.1186/2042-5783-4-2

Vranes J, Schonwald S, Zagar Z (1994): Relation between P-fimbriae and resistance to amoxicillin, carbenicillin and tetracycline in uropathogenic strains of Escherichia coli. Lijec. Vjesn. 116, 178-181

Wu G, Kang H, Zhang X, Shao H, Chu L, Ruan C (2010): A critical review on the bio-removal of hazardous heavy metals from contaminated soils: Issues, progress, eco-environmental concerns and opportunities. J. Hazard. Mater. 174, 1-8 https://doi.org/10.1016/j.jhazmat.2009.09.113

Yamamoto S, Harayama S (1995): PCR amplification and direct sequencing of gyrB genes with universal primers and their application to the detection and taxonomic analysis of Pseudomonas putida strains. Appl. Environ. Microbiol. 61, 1104-1109 https://doi.org/10.1128/AEM.61.3.1104-1109.1995

Zgurskaya HI, Nikaido H (1999a): Bypassing the periplasm: Reconstitution of the AcrAB multidrug efflux pump of Escherichia coli. Proc. Natl. Acad. Sci. USA 96, 7190-7195 https://doi.org/10.1073/pnas.96.13.7190

Zgurskaya HI, Nikaido H (1999b): AcrA is a highly asymmetric protein capable of spanning the periplasm. J. Mol. Biol. 285, $409-420$ https://doi.org/10.1006/jmbi.1998.2313

Zgurskaya HI, Nikaido H (2000a): Multidrug resistance mechanisms: drug efflux across two membranes. Mol. Microbiol. 37, 219-225 https://doi.org/10.1046/j.1365-2958.2000.01926.x

Zgurskaya HI, Nikaido H (2000b): Cross-linked complex between oligomeric periplasmic lipoprotein AcrA and the innermembrane-associated multidrug efflux pump AcrB from Escherichia coli. J. Bacteriol. 182, 4264-4267 https://doi.org/10.1128/JB.182.15.4264-4267.2000

Received: November 4, 2019

Final version accepted: February 26, 2020 
Supplementary Material

\title{
A new type strain of Pseudomonas putida NM-CH-I15-I isolated from a nickel-contaminated soil in southwest Slovakia harbouring the $c z c \mathrm{~A}-\mathrm{NM} 15 \mathrm{I}$ resistance determinant
}

\author{
Nikola Mihalíková ${ }^{1}$, Janka Harichová ${ }^{1}$, Marcel Zámockýl, ${ }^{1,2}$, Anna Kamlárová ${ }^{3}$ and Peter Ferianc ${ }^{1}$ \\ ${ }^{1}$ Laboratory of Phylogenomic Ecology, Institute of Molecular Biology, Slovak Academy of Sciences, Bratislava, Slovakia \\ ${ }^{2}$ Department of Chemistry, Institute of Biochemistry, BOKU, University of Natural Resources and Life Sciences, Muthgasse 18, \\ A-1190 Vienna, Austria \\ ${ }^{3}$ Institute of Experimental Medicine, Faculty of Medicine, Pavol Jozef Šafárik University, Košice, Slovakia
}

Table S1. Primer sets used in this study

\begin{tabular}{|c|c|c|}
\hline Probes & Sequence $\left(5^{\prime} \rightarrow 3^{\prime}\right)$ & Description \\
\hline $27 \mathrm{~F}$ & AGAGTTTGATCCTGGCTCAG & \multirow{2}{*}{$\begin{array}{l}\text { 16S rDNA universal primers, positions 8-27 and 1512-1492 in the } \\
\text { Escherichia coli K12 } \\
\text { [NC_000913] numbering system; (Lane, 1991) }\end{array}$} \\
\hline $1492 \mathrm{R}$ & ACGGCTACCTTGTTACGACTT & \\
\hline ampCF & CGCGCATTACTTCAGCTACG & \multirow{2}{*}{$\begin{array}{l}\text { ampC gene primers, positions 3,277,950-3,277,931 and 3,277,112- } \\
\text { 3,277,131 (negative) in the P. putida KT2440 [NC_002947] } \\
\text { numbering system; This work }\end{array}$} \\
\hline ampCR & CGGTCTTGTTGTACCAGGCT & \\
\hline atpDF & CTGGGCCGSATCATGGACG & \multirow{6}{*}{$\begin{array}{l}\text { Positions of atpD (6,176,350-6,176,332 and 6,175,460-6,175, } \\
\text { (negative)), carA (5,373,076-5,373,057 and 5,372,352-5,372, } \\
\text { (negative)), and recA (1,827,351-1,827,370 and 1,828,016- } \\
1,827,997 \text { (positive)) gene primers in the P. putida KT2440 } \\
\text { [NC_002947] numbering system (Hilario et al. 2004) }\end{array}$} \\
\hline atpDR & GTCCATGCCCAGGATSGCG & \\
\hline carAF & TTCAACACCGCCATGACCGG & \\
\hline carAR & TGATGRCCSAGGCAGATRCC & \\
\hline recAF & TCSGGYAARACCACSCTGAC & \\
\hline recAR & RTACCAGGCRCCGGACTTCT & \\
\hline UP1 & $\begin{array}{l}\text { GAAGTCATCATGACCGTTCTGCA } \\
\text { (TC)GC(TCAG)GG(TCAG)GG(TCAG) } \\
\text { AA(AG)TT(TC)GA }\end{array}$ & \multirow{2}{*}{$\begin{array}{l}\text { gyrB gene primers, positions } 91-104 \text { and } 495-509 \text { amino acid } \\
\text { residues (the numbering corresponds to that of the E. coli } \\
\text { K12 protein [(GYRB_ECOLI in the SWISS-PROT database)]) } \\
\text { (Yamamoto, Harayama, 1995) }\end{array}$} \\
\hline UP2r & $\begin{array}{l}\text { AGCAGGGTACGGATGTGCGAGCC } \\
\text { (AG)TC(TCAG)AC(AG)TC(TCAG)GC } \\
\text { (AG)TC(TCAG)GTCAT }\end{array}$ & \\
\hline UP-1S & GAAGTCATCATGACCGTTCTGCA & \\
\hline UP-2Sr & AGCAGGGTACGGATGTGCGAGCC & \\
\hline pyrHF & ATGGCTCAGCAGGTGAGTG & \multirow{2}{*}{$\begin{array}{l}\text { pyrH gene primers, positions } 1,787,215-1,787,233 \text { and } 1,787,958- \\
1 \text {, } \\
787,940 \text { in the P. putida KT2440 [NC_002947] numbering system; } \\
\text { This work }\end{array}$} \\
\hline pyrHR & TCATGCTTGGCCTTCCTCG & \\
\hline rpoAF & GGTTTCGGCCATACCCTGG & rpoA gene primers, positions 563,017- 563,035 and 563,838- \\
\hline rpoAR & GGCCAGAACGTCCTTGATTTC & $\begin{array}{l}563,818 \text { in the P. putida KT2440 [NC_002947] numbering system; } \\
\text { This work }\end{array}$ \\
\hline rpoBF & CTTTAGCAAGTTGCCGGACG & rpoB gene primers, positions 537,664-537,683 and 538,476- \\
\hline rpoBR & GCCTTCTCGAGCTGGTTGAT & $\begin{array}{l}538,457 \text { in the P. putida KT2440 [NC_002947] numbering system; } \\
\text { This work }\end{array}$ \\
\hline rpoDF & CAACGAAACCGACCAGACCT & rpoD gene primers, positions 472,002-471,983 and 471,170- \\
\hline rpoDR & GCTCACGCGTTACGTCAAAC & $\begin{array}{l}471,189 \text { (negative) in the P. putida KT2440 [NC_002947] } \\
\text { numbering system; This work }\end{array}$ \\
\hline
\end{tabular}

(Continued) 
Table S1. Primer sets used in this study (continued)

\begin{tabular}{|c|c|c|}
\hline Probes & Sequence $\left(5^{\prime} \rightarrow 3^{\prime}\right)$ & Description \\
\hline $14 \mathrm{nccF}$ & TCATCCAATTCGCCATCGAGC & $\begin{array}{l}\text { 2,111,794-2,111,814 czcA primer, position on chromosome in the } \\
\text { P. entomophila L48 [CT573326] numbering system; This work }\end{array}$ \\
\hline 2960nccR & AGCGCAGTCATCAACACTGG & $\begin{array}{l}\text { 3,523-3,504 czcA-NM primer, position on chromosome in the } \\
\text { P. putida NM-CH-I15-I [MG967453] numbering system; This } \\
\text { work }\end{array}$ \\
\hline $1692 \mathrm{nccF}$ & TCTACGATCGCAACCAACCTG & $\begin{array}{l}\text { 1,546-1,565 czcA-NM primer, position on chromosome in the } \\
\text { P. putida NM-CH-I15-I [MG967453] numbering system; This } \\
\text { work }\end{array}$ \\
\hline 2710nccR & TGGGACAGCTCGTAGTTACTG & $\begin{array}{l}\text { 2,563-2,543 czcA-NM primer, position on chromosome in the } \\
\text { P. putida NM-CH-I15-I [MG967453] numbering system; This } \\
\text { work }\end{array}$ \\
\hline $\mathrm{PF} 15 \mathrm{I}-\mathrm{Fb}$ & GAGGTGGTGGACGAGACCAG & $\begin{array}{l}2111250-2111269 \text { primer for upper } c z c \text { A gene region, } \\
\text { position on chromosome in the P. entomophila L48 [CT573326] } \\
\text { numbering system; This work }\end{array}$ \\
\hline PF15I-Rb & TGATGCGCTGCTCGGTTT & $\begin{array}{l}\text { 756-739 czcA-NM gene primer, position on chromosome in the } \\
\text { P. putida NM-CH-I15-I [MG967453] numbering system; This } \\
\text { work }\end{array}$ \\
\hline PF15I-Fe & GCTGATGATGTTCAGCAACCTCAAG & $\begin{array}{l}\text { 3,251-3,275 czcA-NM gene primer, position on chromosome in } \\
\text { the P. putida NM-CH-I15-I [MG967453] numbering system; This } \\
\text { work }\end{array}$ \\
\hline PF15IFc & CTTCGTTCTGAAGTCCGAACT & $\begin{array}{l}\text { 494-514 primer for upper } c z c \mathrm{~A}-\mathrm{NM} \text { gene region, position } \\
\text { on chromosome in the } P \text {. putida NM-CH-I15-I [MG967453] } \\
\text { numbering system; This work }\end{array}$ \\
\hline PF15I-Rc & CAGCACAAACAGACAGTCTTACTCT & $\begin{array}{l}\text { 3,707-3,683 primer for under } c z c \mathrm{~A}-\mathrm{NM} \text { gene region, position } \\
\text { on chromosome in the } P \text {. putida NM-CH-I15-I [MG967453] } \\
\text { numbering system; This work }\end{array}$ \\
\hline PF15I-RT-F & CCGACCTGCGGGTGATCCAG & $\begin{array}{l}c z c \mathrm{~A}-\mathrm{NM} \text { gene primers, positions } 966-985 \text { and } 1089-1077 \text { in } \\
\text { this gene of the } P \text {. putida NM-CH-I15-I [MG967453] numbering }\end{array}$ \\
\hline PF15I-RT-R & CGCTTGAGGTCCGGGGCAAT & system; This work \\
\hline PF15I-gdhA-RT-F & TGTCCGACTCCGAAGGCACG & $\begin{array}{l}\text { gdhA gene primers, positions } 533-552 \text { and } 653-634 \text { in this gene of } \\
\text { the P. putida [AF321093] numbering system; This work }\end{array}$ \\
\hline PF15I-gdhA-RT-R & CCATGGGCGCTCGCAAGTTC & \\
\hline
\end{tabular}

In column Probes: b, beginning of the gene; e, end of the gene; c, complete gene. In column Description: number in parenthesis indicate the GenBank accession number. 

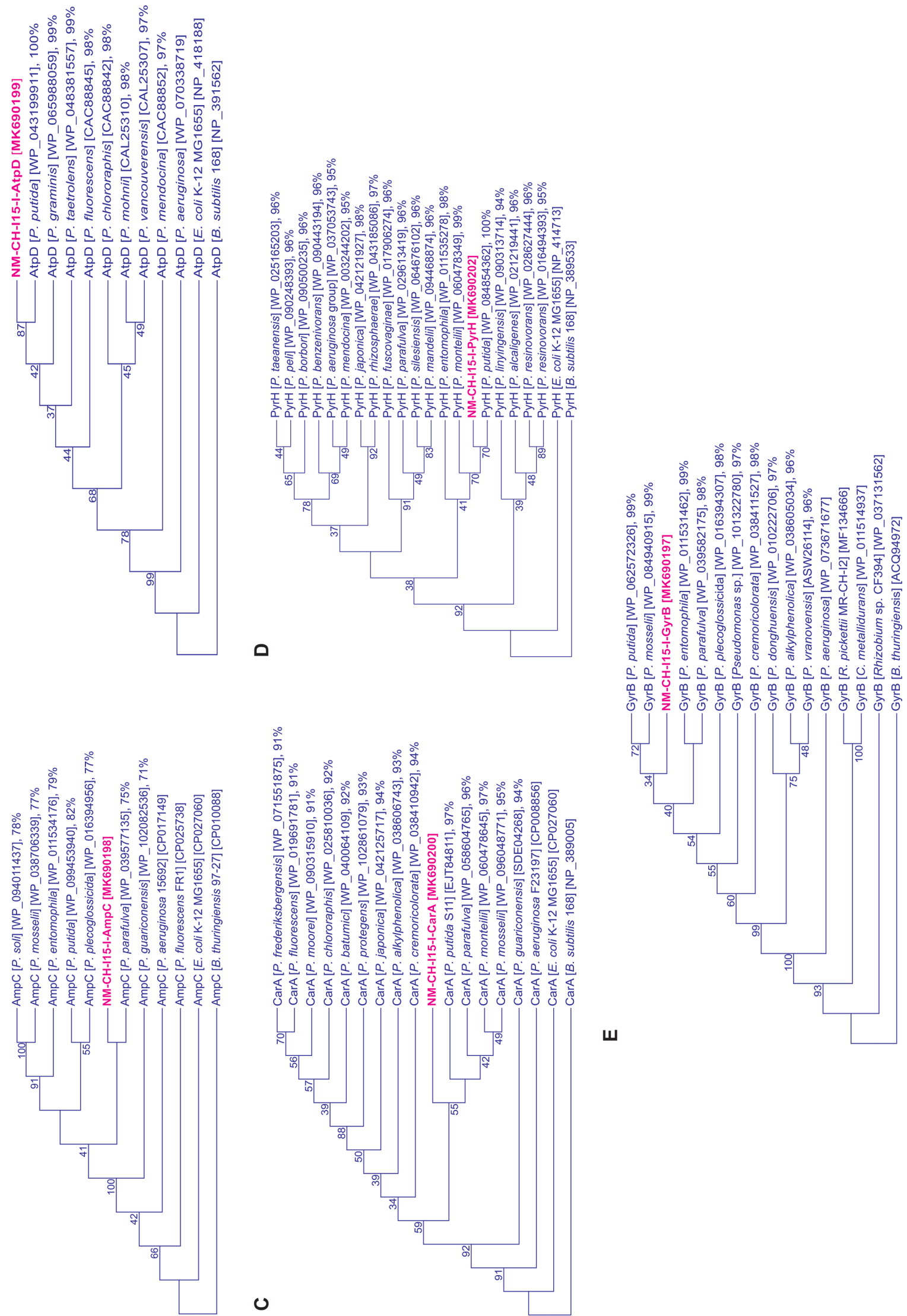

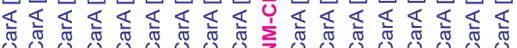
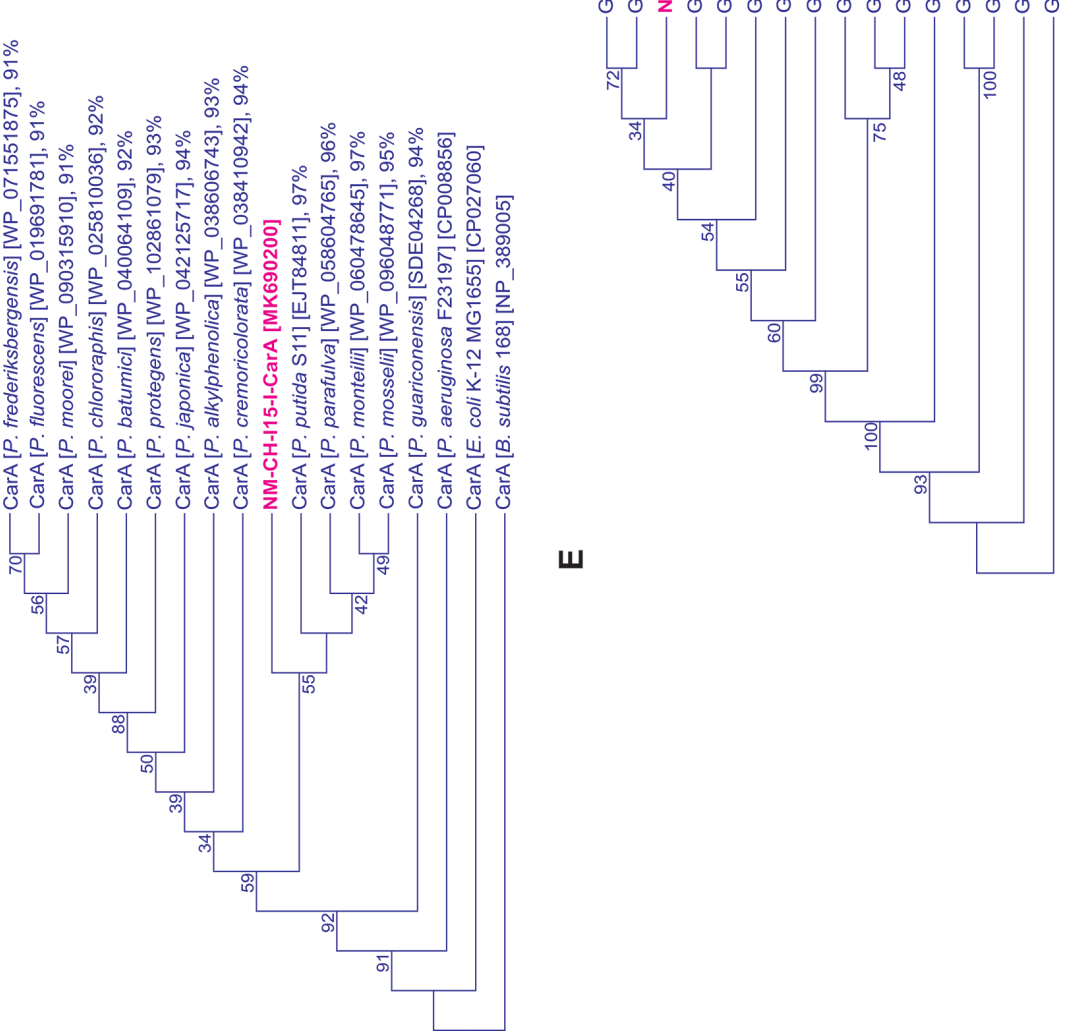

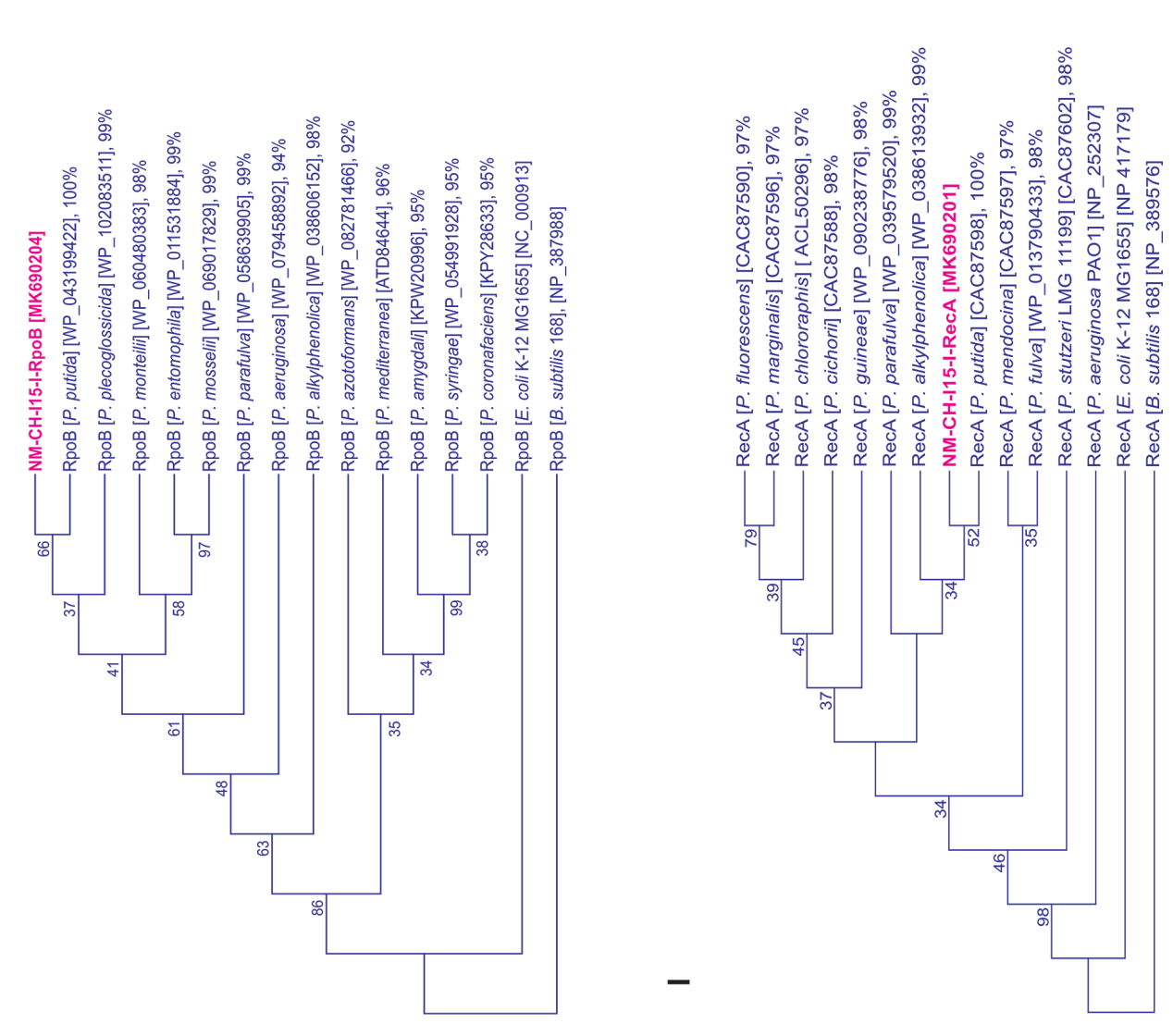

仓ิ

¿

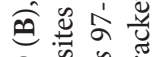

की

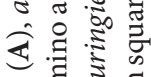

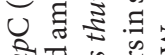

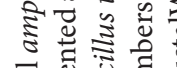

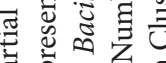

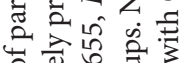

氙志颉

品

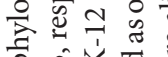

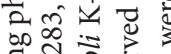

它造

की

虽

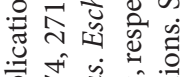

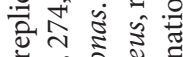

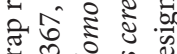

जी

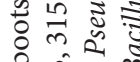

\&

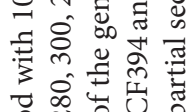

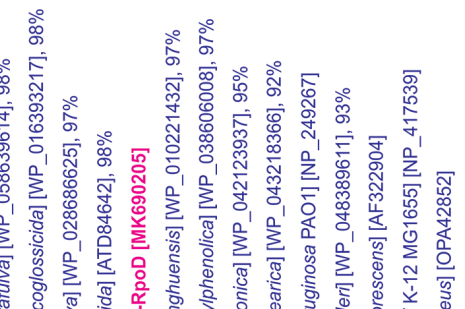

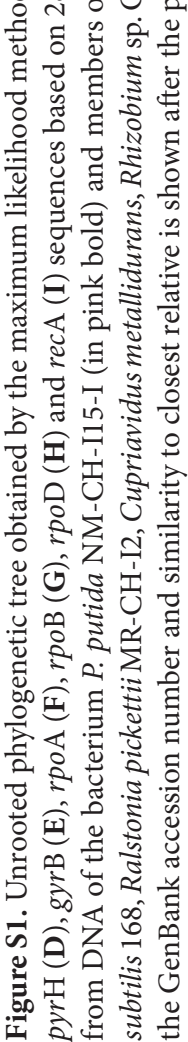

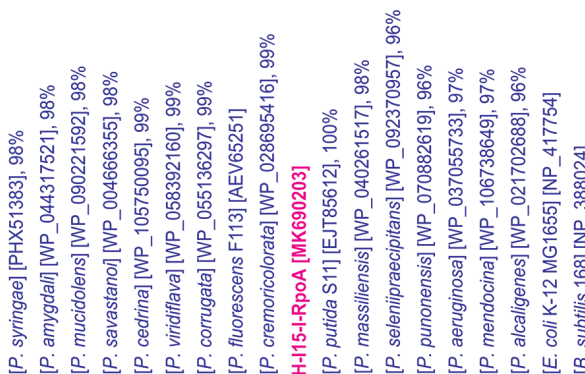

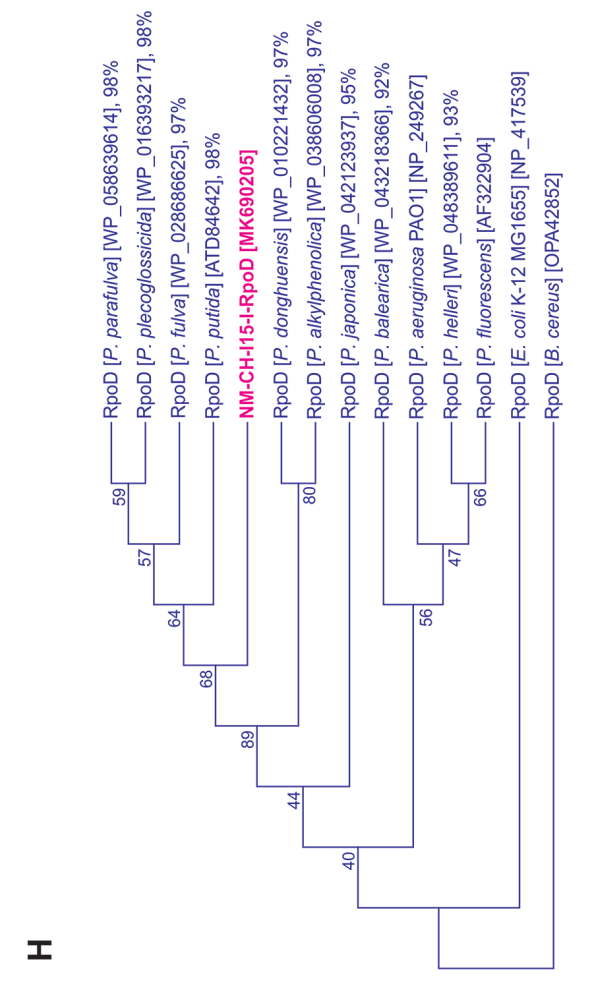

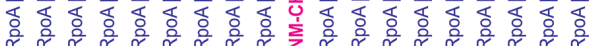

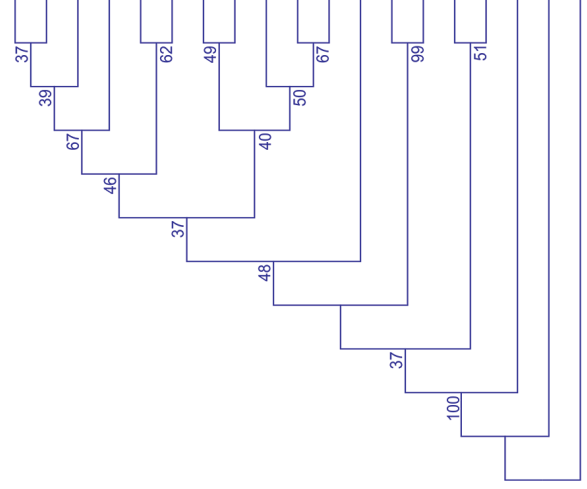

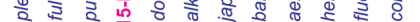

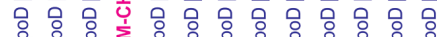

约

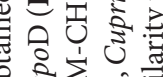

可焉

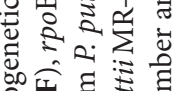

足画焉自

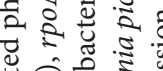

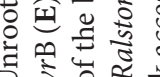

म.

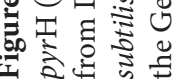




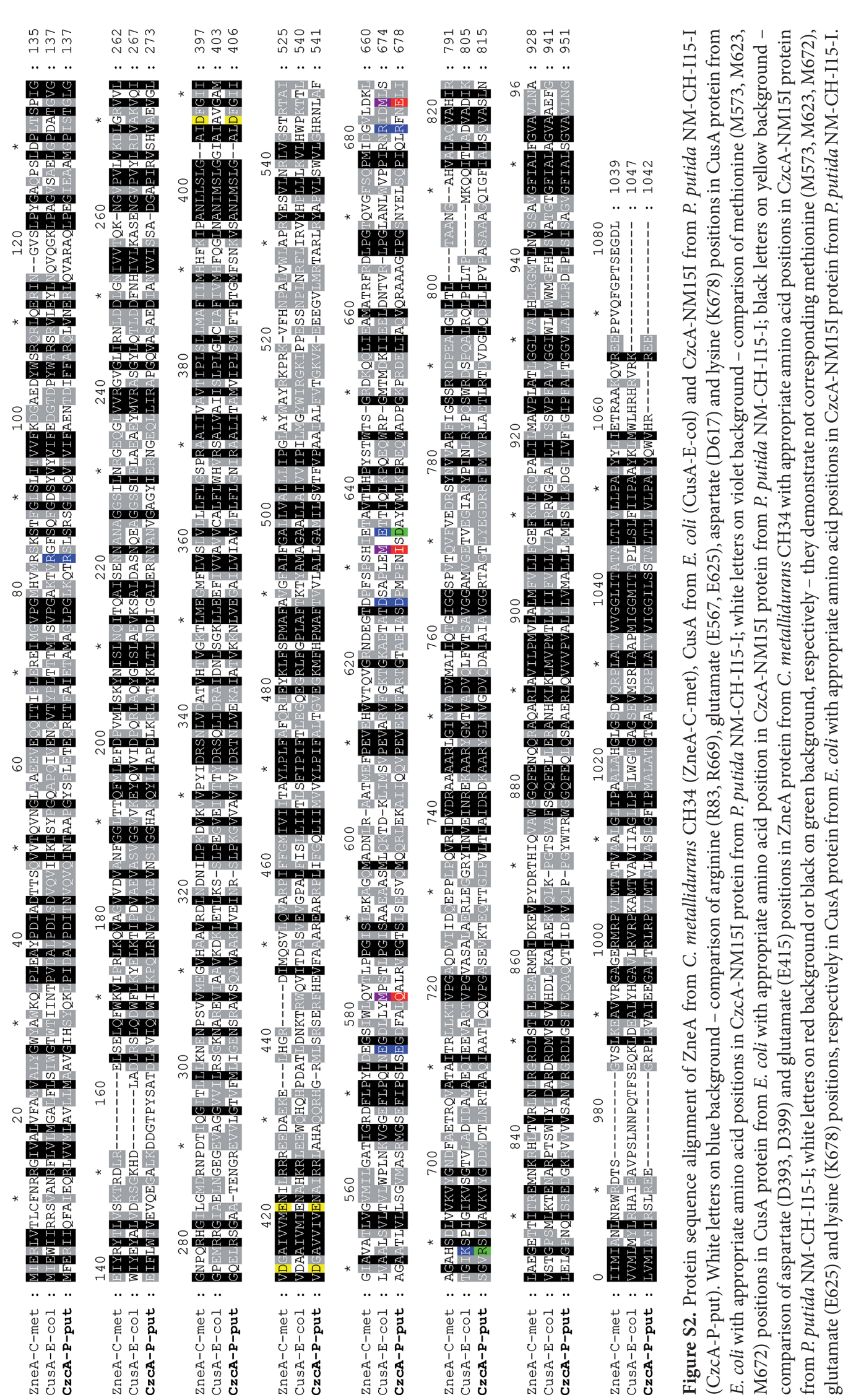

